Article

\title{
Enablers of Entrepreneurial Activity across the European Union-An Analysis Using GEM Individual Data
}

\author{
Ana Iolanda Vodă ${ }^{1}\left(\mathbb{D}\right.$, Gina Ionela Butnaru ${ }^{2, *}$ and Rodica Cristina Butnaru ${ }^{3}$ \\ 1 Social Sciences and Humanities Research Department, Institute for Interdisciplinary Research, Alexandru \\ Ioan Cuza University of Iasi, Lascăr Catargi Street, no. 54, 700107 Iaşi, Romania; yolanda.voda@gmail.com \\ 2 Department of Management, Marketing and Business Administration, Alexandru Ioan Cuza University of \\ Iaşi, Bulevardul Carol I 11, 700506 Iasi, Romania \\ 3 Strategy Social and Environmental Responsibility Department, School of Management Sciences, University \\ of Quebec at Montreal, PO Box 8888, Downtown Branch Montreal, QC H3C 3P8, Canada; \\ reteaca.rodica_cristina@uqam.ca \\ * Correspondence: gina.butnaru@uaic.ro; Tel.: +40-232-201-453
}

Received: 31 December 2019; Accepted: 25 January 2020; Published: 31 January 2020

\begin{abstract}
The objective of this study involves identifying the influence of different perceptual attributes on the likelihood of engaging in early-stage entrepreneurial activities (TEA). The study correspondingly applies individual data based on the statistics gathered from Global Entrepreneurship Monitor (GEM) Adult Population Survey database for 18 European Countries in 2007 and 2014. We performed several logistic regression analyses in order to test the influence of some entrepreneurial attributes on the propensity to engage in TEA. We identified four perceptual determinants: Capability to identify opportunity; having the skills, knowledge and experience to start up a business; fear of failure; and knowing other entrepreneurs. We tested their effect along with some control variables and interaction effects. The results confirm the importance of these factors in explaining entrepreneurial activities across different economies.
\end{abstract}

Keywords: early-stage entrepreneurial activities; self-confidence; fear of failing; perception of opportunities; networking; Global Entrepreneurship Monitor; European Union

\section{Introduction}

Entrepreneurial activity is one of the most important factors contributing to the economic progress of a country [1,2]. Entrepreneurship may stimulate growth by introducing innovations, creating change, creating competition and enhancing rivalry [3]. In the context of an evolving economy, entrepreneurs are important assets because they also contribute to social development [4,5], serve as agents of change by bringing new ideas to markets [6,7], may introduce important innovations by placing on the market new products and services [8], and create an attractive business environment by encouraging the creation of new businesses [9].

In the last years, many researchers have studied the importance of this phenomenon considering three main perspectives: the economic factors $[3,8,10]$, the socio-cultural factors $[5,11]$, and perception determinants [8,12-15]. Yet, several previous studies found some mixed results about the relationships between some perceptual variables and entrepreneurial activities. For instance, according to Özdemir and Karadeniz [6], the fear of failure is not a significant factor influencing the likelihood of engaging in entrepreneurial activities. The authors explain this phenomenon by the characteristics of an individual's national culture, as individuals may be accustomed to the economic instability or uncertainty of their country, which influences their risk perception or fear of failure. Also, other studies comparing different 
regions or countries reveal that entrepreneurial activities and their main determinants may differ in intensity and impact according to the country/region development level $[6,16]$. This may be due to the fact that an important feature of the most developed countries, which are innovation-focused economies, is that SMEs support innovation [8] and represent the most important factor contributing to economic prosperity and job creation [1,3]. Similarly, Beynon et al. [8] consider that developed countries prioritize the companies supporting innovation in their economic growth policies, given that the economy is based on these companies. In the same study, the authors state that in less developed countries with generally necessity-based economies, entrepreneurial activity varies according to the level of economic development (it decreases when the economy is dominated by the manufacturing industry, and increases when it is dominated by the service sector-innovation driven phase), which means that different factor combinations can affect the entrepreneurial activity.

Based on this theoretical background, the aim of this study is to focus on the psychological perspective through perceptual factors, and to analyse the role of entrepreneurial attributes as main determinants which explain early-stage entrepreneurial activity during, and after, the recent economic and financial crisis. To achieve this goal, we focused on the influence of four main entrepreneurial attributes on the propensity to engage in TEA, namely: Capability of identifying opportunity; having the skills, knowledge and experience to start up a business or businesses; fear of failure; and knowing other entrepreneurs [17]. However, given the fact that the entrepreneurial activity determinants are sensitive to time and a country's GDP $[5,18,19]$, the study examines two different moments in time, namely 2007 and 2014, in order to capture the fluctuations in entrepreneurial activities, and the effects of different perceptual factors, in less and high developed European member states.

Although, the specific body of research offers a long list of variables influencing the entrepreneurial activities, some studies offer mixed results. For instance, in certain analyses, the fear of failure is not always statistically significant [20] and does not prevent people from becoming entrepreneurs in certain industries [21]. These results are not coherent with the existing literature on entrepreneurship by Beynon et al. [8]; Albulescu, Tamasila [10], and do not support the fear of failure as a trigger of early-stage entrepreneurial activity. We contribute to the existing literature by expanding the knowledge on the determinants of cross-national variations in entrepreneurial activity across 18 European countries, and in two different time periods: 2007 and 2014.

Secondly, from a methodological perspective, the majority of studies on entrepreneurial activity determinants using GEM data apply logistic regression models to measure the relationship between a dichotomous (dependent) variable and a set of predictors, without taking into consideration the potential moderating effects. To bridge this gap, our analysis accounts for the potential moderating effects of gender and the set of independent variables used in the analysis. The limitation of logit models, and the fact that GEM Adult Population Survey, which included mostly "yes" and "no" answers, limiting the use of a more accurate statistical analysis, we evaluated the relative importance of predictors in logistic models through fully standardised logistic regression coefficient estimations. This method enabled us to determine the relative importance of predictors [22].

In order to achieve its objective, this study presents the following sections: introduction, literature analysis and development of research hypotheses, research methodology, results and discussions and conclusions. The first part includes an analysis on the technical literature in the field, according to factors which influence the entrepreneurial activity. In the second part, the research methodology provides information on the research method, sampling and the description of the variables. The final part contains the results and conclusions of the research.

\section{Literature Review and Research Hypotheses}

\subsection{Entrepreneurship and Entrepreneurial Activity_Conceptual Framework}

According to the data provided by GEM reports 2018/2019 [23], TEA (Total Entrepreneurship Activity) includes two categories of entrepreneurs: (a) early entrepreneurs-oriented towards opportunities, 
aged between 18 and 64 years, attracted to entrepreneurship by opportunity, and by their desire to become independent and to increase their income, and motivated to follow the business opportunities perceived; and (b) early-stage entrepreneurs-people engaged in start-ups only due to the absence of available jobs.

Authors such as Wong et al. [3] analysed TEA rate by measuring the adult proportion in the population with active age, who are either, engaged in the process of starting a business, or active as owners of fresh businesses aged less than 42 months. This measuring is in agreement with the extended definition of entrepreneurs including the "true" entrepreneurs Schumpeterian [24], as well as the owners of managerial businesses. Thus, it is admitted that new businesses are the result of the decision to optimise people selection, which is in agreement with the theoretical framework of Schmitz [25]. TEA rates regarding the opportunity and necessity differentiate the entrepreneurs who are motivated to follow the business opportunities perceived from those who are determined to become entrepreneurs as a last resort, when other options of economic activity are absent or unsatisfactory. The result supports the hypothesis according to which entrepreneurial innovation (innovative entrepreneurship) is positively connected to Gross Domestic Product (GDP) growth [3]. This study considers eighteen European member states divided in two groups based on their annual GDP per capita: Less developed countries, and high developed countries. The data retrieved from Adult Population Survey, Global Entrepreneurship Monitor (GEM) annual survey for 2007 and 2014, shows a TEA growth rate of 31.4\% for high developed European countries, and 51.9\% for less developed European countries. Therefore, the analysis of the entrepreneurial activity offers the possibility to identify the number of people who are actually taking measures to get started in business and also increase the TEA rates [26,27]. Consequently, long-term, entrepreneurship will play an important role in lowering unemployment, growing family incomes, and is instrumental in increasing living standard and quality of life. This leads to the development of sustainable economies [9], because it is also an important contributor to the tax collection from revenues received and remunerations paid.

Santos et al. [5] conducted a quantitative analysis to identify the role of individual characteristics (feeling of self-efficacy, perception of opportunity, model of influence and risk perception) and of social norms (choosing the career, entrepreneur's status and respect, and mass media) in early-stage entrepreneurial activity. The dependent variable is total-early-stage entrepreneurial activity of the people aged between 18 and 64 years, who are either, new-born entrepreneurs or managers-owners of a new business. According to Shane and Venkataraman [12], the analysis of the actions and results of starting a new business should consider the individual and the opportunity. Vogel [28] clarifies the differences between venture ideas and venture opportunities, and suggests that opportunities should not be seen as a single perception. Indeed, opportunity perception implies not only opportunity recognition by individuals, but also their fit, i.e., the individual opportunity nexus [29]. The "opportunity" is an abstract concept [29], and represents an important concept in the entrepreneurship field, but the research on opportunities is in progress [28,29]. In fact, according to Foss and Klein [30], scholars from two extreme positions, argue on whether entrepreneurial opportunities are better identified as objective, "individual/opportunity nexus" (or "discovery" view), or as subjective, created by the entrepreneur (the "creation" view).

The results show that the most important predictor of entrepreneurial activity are individual characteristics, which remain stable during the European crisis, the social norms having a low or no effect on entrepreneurial activity, with slight fluctuations during the crisis.

\subsection{Enablers of Entrepreneurial Activity}

\subsubsection{Gender}

Women's creativity and their entrepreneurial potential contribute to economic growth and the creation of new jobs. According to the latest data presented by the European Commission, women constitute $52 \%$ of the total European population, but only represent $34.4 \%$ of self-employed and $30 \%$ of 
start-up entrepreneurs [31]. In addition, the results show that women-owned enterprises have the most rapid growth. Due to the importance of feminine entrepreneurship in the economic, and social growth and development of a country, some authors take a holistic perspective and use a conceptual framework adapted to understand feminine entrepreneurship and the factors contributing to the entrepreneurial activity [4]. The European Commission intends to support and stimulate feminine entrepreneurship, formulating a detailed plan for 2020 [31].

Neill et al. [11] analyse the perception of business opportunity from a three-dimension perspective: Discovery of opportunity, creation of opportunity, and the combination of the two (discovery-creation of opportunity) in a sample of 165 entrepreneur women engaged in an early-stage entrepreneurial activity with rapid growth in USA. The results show a positive connection between the capacity to discover and to create business opportunities and the vision to create businesses with rapid growth. The results of the study cannot be generalised, because the authors analyse a unique sample of entrepreneurial women, with over ten years of working experience and engagement in the creation of more businesses.

The results of a study conducted by Santos et al. [5] show a significant influence of gender on early-stage entrepreneurial activity. More precisely, the authors state that the gender has a significant effect on entrepreneurial activities. Thus, men are more likely to engage in early-stage entrepreneurship activities than women. In addition, Özdemir and Karadeniz [6] studied entrepreneurs in Turkey, demonstrating that men with a higher income and education level, who are confident in themselves, have the ability to identify business opportunities and are in contact with other entrepreneurs, with a positive likelihood to become entrepreneurs. The authors state that the entrepreneurs in Turkey are in fact mostly men, and men are twice more likely to engage in entrepreneurial activities than women. Furthermore, Haus et al. [32] studied gender differences in entrepreneurial intention and motivational constructs for entrepreneurs in Europe and the USA, by groups of students and non-students. The results show a higher average entrepreneurial intention for men compared to women. Although significant, gender differences in entrepreneurial intention and motivational constructs were small, and could not sufficiently explain the substantial differences in starting a business. However, Mueller et al. [33] shows that, among American business students, the traditional vision of "male entrepreneur" has begun to fade, and a new entrepreneur stereotype appears for future generations of business leaders and entrepreneurs, balancing male and female stereotypical characteristics. Also, the analysis shows that in Spain the entrepreneur is associated with traditional stereotypes with a gender role that persists even among business students. Therefore, Wilson et al. [34] analyse two different groups, in three different stages of education and career development, and state that entrepreneurial self-efficacy is very important and a key component in understanding the entrepreneurial interest and real choice of career, education, and positively influencing self-efficacy, which is stronger for women than for men. In considering the socio-economic factors, the research results of Micozzi et al. [20] show that gender and self-confidence play a significant and consistent role on entrepreneurial attitude, being the driving force of entrepreneurial intention, while fear of failure and belief in status are not always statistically significant or homogeneous in the relationship.

Taking into account the relevance of gender against the entrepreneurial activity, the study proposes to test the following hypothesis:

Hypothesis 1 (H1). Men were more likely to engage in early-stage Entrepreneurial Activity than women.

\subsubsection{Age}

In the study conducted by Santos et al. [5], the control variable of age showed a significant influence on the early-stage entrepreneurial activity. The results of the analysis show that age has a significant effect on entrepreneurial activities. Thus, younger people are more likely to engage in early entrepreneurial activities than older people. Bohlmann et al. [35] also studied the relationship between 
age and entrepreneurial activity. From the results, the authors confirmed the hypotheses that, "age significantly influences the entrepreneurial activity" and "age significantly relates to the opportunities perceived by entrepreneurship". The results of this research confirm that age can be studied as an important variable, and young people and older adults represent a group who must be supported differently throughout the entrepreneurial process. By comparison, younger adults appear to have less difficulty in perceiving opportunities and admitting it, they are sufficiently capable of acting entrepreneurially, while older adults have a lower future perspective, their physical cognitive abilities may be declining, consequently they are less likely to perceive opportunities and skills. In addition, the study conducted by Özdemir and Karadeniz [6] shows that age has also significant effects on the likelihood to be engaged in entrepreneurial activities for the entrepreneurs in Turkey. Indeed, the older the employees, the less they are inclined to engage in entrepreneurial activities, and their entrepreneurial intention is lower as they identify more with their work [36]. This study highlights the impact of age on the entrepreneurial potential of older employees, and seems to limit the potential of entrepreneurship in an aging workforce, as a strategy to strengthen innovation and competitiveness of companies.

Taking into account the relevance of age in the engagement in entrepreneurial activities, the study proposes to test the following hypothesis:

Hypothesis 2 (H2). Younger individuals are more likely to engage in entrepreneurial activities than older people.

\subsection{Entrepreneurial Opportunity}

Shane and Venkataraman [12] define the concept of entrepreneurial opportunity as marked by situations when the entrepreneur makes a profit after the sale of goods or services at a higher price than the cost of their production. The discovery of a business opportunity is a mandatory condition for entrepreneurship, and although the awareness of entrepreneurial opportunities is a subjective process, the opportunities themselves are objective. Entrepreneurial opportunities exist only when people perceive them, and involve the discovery of new means-ends relationships. Individual perception of opportunities appears to be the main motivating factor that triggers entrepreneurial behavior $[11,13,14]$. Therefore, the decision to exploit an entrepreneurial opportunity is also influenced by the individual differences in perceptions. According to Shane and Venkataraman [12], not all potential entrepreneurs are able to exploit opportunities with the same estimated value. This decision involves the evaluation of the connection between the opportunity value and the costs of generating that value, as well as the costs which may generate value in other ways. Most of the time, the entrepreneurial opportunity is the starting point of the entrepreneurship process [5], and it is a distinctive characteristic in the analysis of entrepreneurial behavior [8,35]. Bohlmann et al. [35] explains the positive relationship between entrepreneurial opportunities perceived and entrepreneurial activities. More precisely, the results demonstrate that the people who perceive business opportunities are more likely to engage in early-stage entrepreneurial activities. In addition, the longitudinal study conducted by Santos et al. [5] on a total sample of 151,400 entrepreneurs indicates a positive influence of opportunity perception on entrepreneurial intentions in the following countries: Portugal, Italy, Greece, Spain, Sweden, Finland and Norway. However, the authors state that the influence of perception of entrepreneurial opportunity is less important than the influence of the feeling of self-efficacy on the engagement in early entrepreneurial activity. Beynon et al. [8] mention the importance of opportunity perception in the creation of entrepreneurial opportunities, contribute much more to economic growth than the perception of necessity. Furthermore, Ardichvili et al. [37] proposed a theory about the process of identifying the opportunity, and they identified the entrepreneur's personality traits, the social networks, and the prior knowledge as an antecedent of the entrepreneurial awareness of business opportunities. They highlight some important elements concerning the process of opportunity identification: A high level 
of entrepreneurial alertness, the use of an extensive social network, knowledge of special interest and industry knowledge, prior knowledge of markets, prior knowledge of ways to serve markets, high levels of creativity, and entrepreneurial optimism. Therefore, entrepreneurial awareness is a necessary condition for the success of the triad of opportunity identification: Recognition, development and evaluation. In conclusion, the higher the number of previous successful opportunity identification, the greater the likelihood of future successful opportunity identification.

Vaghely and Julien [38] tested a model of human information processing, which provides a framework of entrepreneurs better understanding of the use of information to identify opportunities on a sample of ten SMEs (a case study of ten SMEs). In cognitive psychology, as well as in social constructionism and developmental psychology, there are two streams of thought related to identifying opportunities and processing human information. The cognitive approach of information processing is based on an algorithmic model. The information shapes the representation of the entrepreneur's reality in a normative way; entrepreneurs compare their representations of the environment to outline the logic of their networks. The information is explicit, codable, and therefore, formal. Linking information patterns from various sources is the basis of innovation and new business opportunities. The constructionist perspective is based on a heuristic model. Entrepreneurs process information in an interpretive way; they build their reality using information from their environment. In order to share information, to create new knowledge and innovation and to build opportunities, the entrepreneur must justify the beliefs based on that information. These types of information are the key to innovation and new business opportunities. The conclusions of this study show that the entrepreneurs' information processing is a dynamic combination of algorithmic and heuristic information processing.

We can see that opportunity perception is a wide concept with different significance in relation to entrepreneurial activity. Taking into account the relevance of entrepreneurial opportunities on early-stage entrepreneurial activity, the study proposes to test the following hypothesis:

Hypothesis 3 (H3). The more the individual recognizes an opportunity to act upon, the greater the likelihood of engaging in entrepreneurial activity.

\subsection{Fear of Failure}

Another very important characteristic in the analysis of early entrepreneurial activity is the fear of failure. The entrepreneurs are people who measure and assume the risks of their business [5,6]. Fear of failure (fearfail) measures a negative emotion resulting from the perception of different threats and it is considered a constraining factor for venture creation [10]. The perception of opportunity takes place in a context marked by uncertainty, which prevents action by compromising the convictions of the potential entrepreneur regarding the feasibility of the opportunity [14]. In addition, the uncertainty of not being able to meet the objectives expected in the entrepreneurial activity determines the fear of failure, which prevents them in engaging in entrepreneurial activity [8]. Santos et al. [5] explains the notion of propension to risk defined as the entrepreneurs' choice to risk or to avoid risk in their actions. Risk perception is the estimation of entrepreneurial risk. The authors confirm that people who perceive risk are less likely to engage in early entrepreneurial activities. The results of the study show that risk perception is the least factor influencing an entrepreneur's individual characteristics in early entrepreneurial activity. Özdemir and Karadeniz [6] obtain opposite results than the literature, i.e., the fear of failure is not a significant factor influencing the likelihood of engaging in entrepreneurial activities in Turkey. The authors explain this phenomenon by the characteristics of national culture. Turks may be accustomed to the economic instability or uncertainty of their country, which influences the risk perception or the fear of failure. In this regard, Wennberg et al. [39] demonstrate that the cultural characteristics of a country influence the way by which both fear of failure and self-efficacy are perceived. Hofstede [40] defines the dimensions of national culture, and he states that the level of collectivism is the degree in which the people of a country prefer to act as members of a group, 
and that the level of avoidance of uncertainty is the degree in which the people of a country prefer structured situations, rules, because they are not comfortable with unknown situations. The results of the study conducted by Wennberg et al. [39] show that the level of institutional collectivism and the level of avoidance of uncertainty in a country, influence the way by which the entrepreneur perceives both, fear of failure and self-efficacy, as well as influence the likelihood of entering entrepreneurship. The entrepreneur's perception of fear of failure is an important concept, which differs according to the country. Furthermore, Wyrwich et al. [41] analysed the effect of role-playing games/models on the fear of failing observers using a simple sender-receiver model. Furthermore, they identified that there was no discrepancy impact of knowing an entrepreneur with a fear of failure for younger East Germans, and there existed significant disparities for older East Germans. Entrepreneurs reduce the fear of failure in other environments where approval of entrepreneurship is high, while this effect is significantly weaker in low-approval environments. Arafat et al. [21] studied the determinants of entrepreneurship in the agricultural industry using APS (Adult Population Survey) data from 69 countries provided by GEM 2013 [42]. The results showed that the fear of failure or the perception of risk does not prevent people from becoming entrepreneurs, and moreover, this finding is at odds with the existing literature on entrepreneurship, which shows that the fear of failure discourages entrepreneurial activity.

Taking into account the results of previous studies, which demonstrate the influence of entrepreneurs' fear of failure on their likelihood of engaging in early entrepreneurial activity, the study proposes to test the following hypothesis:

Hypothesis 4 (H4). Fear of failure is positively and significantly associated with the early-stage entrepreneurial activity.

\subsection{Self-Confidence (Suskills)}

Self-confidence (suskills) assesses individuals who consider that skills, knowledge and experience are important for starting a business. Wilson et al. [43] say that "Self-efficacy, or self-confidence in a given domain is based on individuals' self-perceptions of their skills and abilities" (page 389). According to Santos et al. [5], self-confidence proves to be a critical variable positively influencing entrepreneurial intentions, behaviours, and actions. Shane et al. [13] explain the notion of self-efficacy as the trust in the entrepreneur's ability to join and implement the necessary personal resources, including skills and competences, with the purpose to obtain a certain level of performance of a given task in a year. Self-efficacy may be regarded a specific self-confidence for a task. It is a robust predictor of individual performance in a year, and helps explain the reason for which people with equal skills may have different results. A person with high self-confidence for a given task makes more effort and for a longer time, persists in delays, establishes and accepts higher objectives, and makes better plans and strategies for the given task, takes negative feedback more positively, and uses that feedback to improve performance. These attributes of self-confidence can be important in entrepreneurship, because these situations are often ambiguous, where effort, perseverance, and planning are important. Baum and Locke [44] studied the relationship between entrepreneurial characteristics and habits (passion, tenacity and new resource skills), and the motivations specific to the situation (communicated vision, self-confidence and objectives) for the subsequent risk increase. The sample included 229 entrepreneurs-executive directors, and 106 associates in a single industry, the study being longitudinal on 6 years. The results show that objectives, self-confidence and communicated vision had direct effects on risk increase. These factors mediated the effects of passion, tenacity, and new resource skills for subsequent growth. The authors connected the communicated vision and self-efficacy to the objectives, and the tenacity to learn new skills. Furthermore, Bohlmann et al. [35] analysed the relationship between age and perception of skills, which is significant, and the relationship between the skills perceived and the entrepreneurial activity is positive. Chaudhary et al. [45] suggest that self-confidence is important in distinguishing entrepreneurs from non-entrepreneurs. 
The results demonstrate that self-confidence exerts direct effects on the development of entrepreneurial activity, and skills, knowledge and experience are very important for starting a business. Wilson et al. [43] analysed self-efficacy patterns across two different life stages (teen girls who are less experienced, and adult female MBA students), and identified the same self-efficacy patterns in both groups.

Taking into account the importance of self-confidence in the entrepreneurial development process, the study proposes to test the following hypothesis:

Hypothesis 5 (H5). The greater the skills, knowledge and experience, the higher the propensity to engage in entrepreneurial activity.

\subsection{Networking}

The social network proved to be stimulating for business growth, creating new opportunities for engaging in entrepreneurial actions and overcoming liabilities when entering entrepreneurship [46,47]. Along the same lines, Santos et al. [5] analyse the entrepreneurs' perception regarding the models in their entourage. The results of the research, conducted by these authors, show that the perception of the model is indirectly connected to the engagement in the learning process, which helps increase the individual's feeling of self-efficiency. Furthermore, the people who know a business-person (who will bear the role of a model) and have the ability to perceive entrepreneurial opportunities are more likely to engage in early entrepreneurial activities. Alayis et al. [48] introduced in their research the concept of Social Networking Sites (SNS, websites and apps), which enable contact with other individuals with similar interests, thereby confirming the influence of SNS on students' perceived feasibility. Furthermore, Ratten et al. [49] state that entrepreneurial and network knowledge influence the individual's intention to start a business.

On the other hand, the significant impact of model perception and opportunity perception is lower than the self-efficiency coefficient, so it contributes much less to the engagement of the potential entrepreneur in early-stage entrepreneurial activity than the feeling of self-efficacy. Özdemir and Karadeniz [6] explain that, in fact, the higher the education level, the more we are in contact with more models (knowing other entrepreneurs-social networking). The authors state that perception variables: social networking, opportunity perception, and the feeling of self-efficacy positively correlate, and together they all significantly correlate with the fear of failure. Schmutzler et al. [50] demonstrate that social networking differs in intensity from one country to the other, and models of influence lead to the increase of entrepreneurial intentions in more individualist socio-cultural contexts. Consequently, some results from the literature state that women with a higher engagement to the family engage less in social networking, which could affect entrepreneurial activity [4].

Taking into account the positive influence of networking in the process of starting an early-stage entrepreneurial activity, the study proposes to test the following hypothesis:

Hypothesis 6 (H6). Networking will exert a positive and significant influence on early-stage entrepreneurial activity.

Table 1 presents the main contributions from the literature on the entrepreneurial activities and determinant factors. 
Table 1. Summary of literature review.

\begin{tabular}{|c|c|c|}
\hline Variable & Authors & Expected Sign \\
\hline Entrepreneurial activity & $\begin{array}{c}\text { Wong et al. [3]; Santos et al. [5]; Beynon et al. [8]; } \\
\text { Bosma, Kelley [23] }\end{array}$ & \\
\hline Entrepreneurial opportunities & $\begin{array}{c}\text { Beynon et al. [8]; Neill et al. [11]; Shane et al. [13]; } \\
\text { McMullen, Shepherd [14] }\end{array}$ & $“+”$ \\
\hline Fear of failure & Beynon et al. [8]; Albulescu, Tamasila [10] & 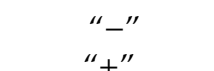 \\
\hline Self-confidence & Santos et al. [5], Shane et al. [13]; Bohlmann et al. [35] & “+” \\
\hline Networking & $\begin{array}{c}\text { Özdemir, Karadeniz [6]; Turkina [46]; Welter [47]; } \\
\text { Schmutzler et al. [50] }\end{array}$ & “" \\
\hline Respondent's gender & $\begin{array}{c}\text { Brush et al. [4]; Santos et al. [5]; Neill et al. [11]; } \\
\text { Velilla [16] }\end{array}$ & “-" \\
\hline Respondent's age & $\begin{array}{c}\text { Santos et al. [5]; Özdemir, Karadeniz [6]; Bohlmann } \\
\text { et al. [35] }\end{array}$ & “-" \\
\hline
\end{tabular}

Source: Author's contribution.

\section{Materials and Methods}

The objective of our analysis focused on studying the role of adult populations' attitudes regarding entrepreneurship. Our goal is to measure the effects of entrepreneurial attitudes, such as the capability to identify opportunity, having skills, knowledge and experience to start up businesses, fear of failing, and knowing other entrepreneurs on the likelihood to engage in early-stage entrepreneurial activity. In order to analyse the influence of these perceptual factors and entrepreneurial activity, we used data retrieved from Adult Population Survey, Global Entrepreneurship Monitor (GEM) annual survey for 2007 and 2014, and a total of 18 European countries. We selected the countries based on data availability for the period analysed [26,27].

We chose Global Entrepreneurial Monitor (GEM) because it is one of the few standardised datasets on entrepreneurship. GEM enables across-national comparison, and provides a robust framework for analysing different aspects of entrepreneurships. GEM data not only provides a broad overview on entrepreneurship, but also focuses on the behaviour of individuals with respect to starting and managing a business. Also, with minor exceptions, the data for each of the selected country contains a representative sample of working-age population of 2000 or more. The number of variables used in the modelling procedure are described in Table 2. The study uses logit regression models to estimate the probability that individuals belonging to a specific group have a high susceptibility to several cognitive biases. We selected the log-it regression analyses because the vast majority of the variables were dichotomous, including our dependent variable. This type of analysis enabled us to estimate the effect of perceptual factors, interactions and control variables on the probability of engagement in entrepreneurial activities. The total sample used in the analysis is divided into two groups:

- G1-Less developed countries: Croatia, Greece, Hungary, Latvia, Portugal, Romania, Slovenia and Spain;

- G2-High developed countries: Belgium, Denmark, Finland, France, Germany, Ireland, Italy, The Netherlands, Sweden and United Kingdom.

The delimitation criteria for the two groups were based on annual GDP per capita (using data provided by World Bank [51]. Countries with income below the average mean were classified as G1 and those with the level of income above the average mean were classified as G2. 
Table 2. Description of the variables.

\begin{tabular}{|c|c|c|c|}
\hline Variable & Code & Description & Type \\
\hline Entrepreneurial activity & TEA & $\begin{array}{l}\text { Total Early-Stage Entrepreneurial Activity }(T E A) \text { : The respondent is asked whether she/he is involved in early } \\
\text { stage entrepreneurial activities. A dichotomous variable coded by } 1 \text {-engaged in early stage entrepreneurial } \\
\text { activities and } 0 \text { otherwise. }\end{array}$ & Binary \\
\hline Opportunity perception & OPPORT & $\begin{array}{l}\text { Perception of good opportunities to start up a new business: The respondent is asked whether she/he believes } \\
\text { that in the next six months there will be good opportunities to start up new businesses in the area she/he lives. } \\
\text { A dichotomous variable coded 1- if the respondent replies affirmatively to the question and } 0 \text { otherwise. }\end{array}$ & Binary \\
\hline Fear of failure & FEARFAIL & $\begin{array}{l}\text { Fear of fail attitude: The respondent is asked whether the fear of failure would be an obstacle for launching a } \\
\text { business. A dichotomous variable coded by 1-positive answer and } 0 \text { otherwise. }\end{array}$ & Binary \\
\hline Self-confidence & SUSKILL & $\begin{array}{c}\text { Confidence in their own knowledge, skills and experience: The respondent is asked whether she/he believes } \\
\text { that she/he has the necessary knowledge, skills, and experience to start up a new business. The dichotomous } \\
\text { variable coded by 1-postive answer to the question and } 0 \text { for a negative one. }\end{array}$ & Binary \\
\hline Networking & KNOWENT & $\begin{array}{l}\text { Networking: Do you know someone personally who started a business in the past } 2 \text { years? The dichotomous } \\
\text { variable coded by 1-postive answer to the question and } 0 \text { for a negative one. }\end{array}$ & Binary \\
\hline $\begin{array}{l}\text { Respondent's } \\
\text { gender }\end{array}$ & GENDER & The respondent indicates her/his gender (1-male; 2 -female) & Categorical \\
\hline $\begin{array}{l}\text { Respondent's } \\
\text { age }\end{array}$ & $A G E$ & The respondent was asked to provide the year of birth. & Numerical \\
\hline
\end{tabular}




\section{Dependent Variable}

The dependent variable used in our research is:

- Entrepreneurial activity (indicates how entrepreneurial societies really are). For measuring the level of entrepreneurial activity, we used as proxy the total early-stage entrepreneurial activity (TEA). The variable includes the category of population aged between 18 and 64 who is either actively trying to start a new business, or managing a business which is less than three-and-a half years old. TEA includes two categories of entrepreneurs: a) opportunity-driven early stage entrepreneurs (the respondents aged 18-64 who are pulled to entrepreneurship by opportunity and their desire to become independent and increase their income, and who are motivated to pursue perceived business opportunities), and b) necessity-driven early-stage entrepreneurs (individuals involved in start-ups only because of the lack of jobs) [23]. TEA is measured as a dichotomous variable which takes the value" 1 " if the respondents answer affirmatively to their involvement in early stage entrepreneurial activities, and " 0 " otherwise. This approach to measure entrepreneurial activities by a single item proxy has been widely accepted and used by researchers [3,5].

\section{Independent Variables}

The independent variables gather information on entrepreneurial attitudes: capability to identify opportunity (opport), self-confidence (suskills), fear of failing (fearfail), and networking (knowent).

- Entrepreneurial opportunities exist only when people perceive them, and involve the discovery of new means-ends relationships [12]. Individual perception of opportunities appears to be the main motivating factor triggering entrepreneurial behaviour [11,13,14]. In the present research, opportunity perception (opport) measures the individuals who consider that in the next six months there will be good opportunities to start a firm, in the area they live. The variable is dichotomous, with the value coded by "1" for an affirmative answer, and " 0 " otherwise.

- Self-confidence (suskills) measures the people who consider important having skills, knowledge and experience when starting up a business. The question used for self-confidence assessment was: "Do you have the knowledge, skills and experience required to start a new business?" The dichotomous variable takes the value " 1 " if the respondent's reply is "yes" to the question, and "0" otherwise.

- Fear of failure (fearfail) measures a negative emotion resulting from the perception of different threats, being a constraining factor for venture creation [10]. The individuals were asked whether fear of failure would prevent them from starting a business. If the answer is affirmative, the variable is coded by " 1 ", and " 0 " otherwise.

- Networking proved to be stimulating for business growth, creating new opportunities for engaging in entrepreneurial actions and overcoming liabilities when entering an entrepreneurship [46,47]. In the analysis, networking (knowent) is a dichotomous variable taking the value " 1 " if the respondent answers affirmatively to the question: "Do you personally know someone who started a business in the past 2 years?", and "0" otherwise.

\section{Control Variables}

In the research we use the following control variables:

- Gender-a dummy variable with the value " 1 " for men and "0" for women;

- Age, the respondent was asked to provide the year of birth. We included in the analysis the respondents aged between 18 and 64 .

We test our hypotheses using binary logistic models, and by predicting the likelihood of the effects of several attitudinal factors on entrepreneurial activities, using SPSS 21.0 software. The dichotomous dependent variable takes the value " 1 " with a probability of success q (where 1 expresses involvement in TEA), or the value " 0 " with the probability 1-q (not involved in entrepreneurial activities). We apply this type of analysis as our dependent variable and most independent variables are dichotomous. 
Developed as such, the analysis allows us to show the effect of the independent variables on the probability to engage in early stage entrepreneurial activities.

The model takes the following general form,

$$
\ln \left(\frac{\pi}{1-\pi}\right)=\beta_{0}+\sum_{i=1}^{k} \beta_{i} X_{i}+\varepsilon
$$

where: $\pi$ is $\operatorname{Prob}\left(Y=1 \mid X_{1}, X_{2}, \ldots, X_{i}\right)$, y is the dependent variable and represents an observable variable indicating the probability of involvement in entrepreneurial activities, $\beta_{0}$ is the intercept, $X_{i}$ represents the vector of independent variables and control variables, $\beta_{i}$ represents the coefficients, $\varepsilon$ is the error term.

The above general form of the model can be rewritten in the following exponential form,

$$
\operatorname{Prob}\left(Y=1 \mid X_{1}, X_{2}, \ldots, X_{i}\right)=\frac{e^{\beta_{0}+\sum_{i=1}^{k} \beta_{i} X_{i}}}{1+e^{\beta_{0}+\sum_{i=1}^{k} \beta_{i} X_{i}}}
$$

where: $X_{i}, i=\overline{1, k}$ denotes the explanatory and control variables, and $\operatorname{Prob}\left(Y=1 \mid X_{1}, X_{2}, \ldots, X_{i}\right)$ expresses the probability to obtain the value $Y=1$ conditioned by the values of $X_{i}$.

We assessed the goodness-of-fit of the models using Omnibus Test, Cox \& Snell Pseudo $R^{2}$, Nagelkerke $R^{2}$, indicating the usefulness of the explanatory variables in predicting the response variable, and -2 Log Likelihood. Also, we presented the value for Wald $\chi^{2}$ statistics, testing the significance of individual coefficients, where $\chi^{2}$ is given a single degree of freedom. In logistic regression, the odds ratio $(\operatorname{Exp}(\beta))$ represents the constant effect of a predictor $X$, in the likelihood that one outcome will occur. The odds ratio is a single summary score of the effect.

In the literature, evidence shows that entrepreneurial activity determinants are sensitive to time and country GDP $[5,18,26]$. Starting from this theoretical background, we consider that entrepreneurship research must focus on how different periods may shape the pattern of relationships between variables, in different contexts. In order to achieve this aim, several logistic regressions will be performed on two groups of countries (less developed (G1) and high developed economies (G2)), in two different time periods.

Moreover, in order to compare the relative influence of different predictors or independent variables within a logistic regression model, we standardized the predictors based on Menard [22] approach. The fully standardized logistic regression coefficients can be estimated based on the following equation,

$$
b_{M}^{*}=(\mathrm{b}) \cdot\left(S_{X}\right) \cdot(\mathrm{R}) / S_{\operatorname{logit}(\hat{\mathrm{Y}})}
$$

where $b$ is the sample estimate of the unstandardized logistic regression coefficient and $S_{X}$ is the sample standard deviation of the predictor X. $b_{M}^{*}$ may be described as a fully standardized logistic regression coefficient which incorporates the empirical variation in the dependent variable, as well as the predictors. Given the fact that $R^{2}$ is,

$$
R^{2}=S_{\hat{Y}}^{2} / S_{Y}^{2}
$$

where $S_{\hat{Y}}$ is the standard deviation of the predicted values of $Y$, it results that $S_{Y}=S_{\hat{Y}} / R$ for OLS, and for logistic regression $S_{\operatorname{logit}(Y)}$ may be estimated as $S_{\operatorname{logit}(\hat{Y})} / \mathrm{R}$. Therefore, to divide by $S_{\operatorname{logit}(Y)}$ (to obtain the standardized coefficient) is equivalent to multiplying by $R / S_{\text {logit }(\hat{Y})}[22]$.

We present the results and interpretation of the empirical analysis in the following section.

\section{Results and Interpretation}

Table 3 shows descriptive statistics and correlations. As we can see, the correlations among the included variables are not very strong, as all coefficients of independent variables have values ranging from 0.020 to 0.232 in 2007, and from 0.020 to 0.223 in 2014 . The relationship between the independent 
variables and the dependent variables can be distorted, as there is a strong relationship between the items analysed. From the data available in Table 3, we can see that in our analysis the coefficient values are not very high (this implies that the coefficient values are not 0.90 or higher), meaning that multi-collinearity is not an issue for the analysis. From the total sample, only $5 \%$ of the respondents were involved in entrepreneurial activities, $27 \%$ found good opportunities in the area where they lived, $45 \%$ considered that fear of failure would prevent them being actively involved in TEA, $47 \%$ considered that knowledge and skills were important in a business, and 33\% considered networking an important factor for entrepreneurial activity. Figure 1 provides a more in-depth overview of the distribution by country of the percentage of individuals actively involved in entrepreneurial activities in 2007 and 2014. Countries from G1 have a higher percentage of individuals involved in entrepreneurial activities in $2007(5.85 \%)$ and 2014 (8.33\%) than those from G2 (4.53\% in 2007, and 5.99\% in 2014). From G1, countries like Portugal (9\%), Spain (7.3) in 2007 and Latvia (12.8) and Romania (11\%) in 2014 recorded the highest individual involvement in entrepreneurial activities. From G2, Ireland (7.1\%) and Finland $(6.8 \%)$ recorded the highest values in 2007 and The Netherlands $(8.1 \%)$ and United Kingdom $(7.9 \%)$ in 2014 (Table A1 in Appendix A).

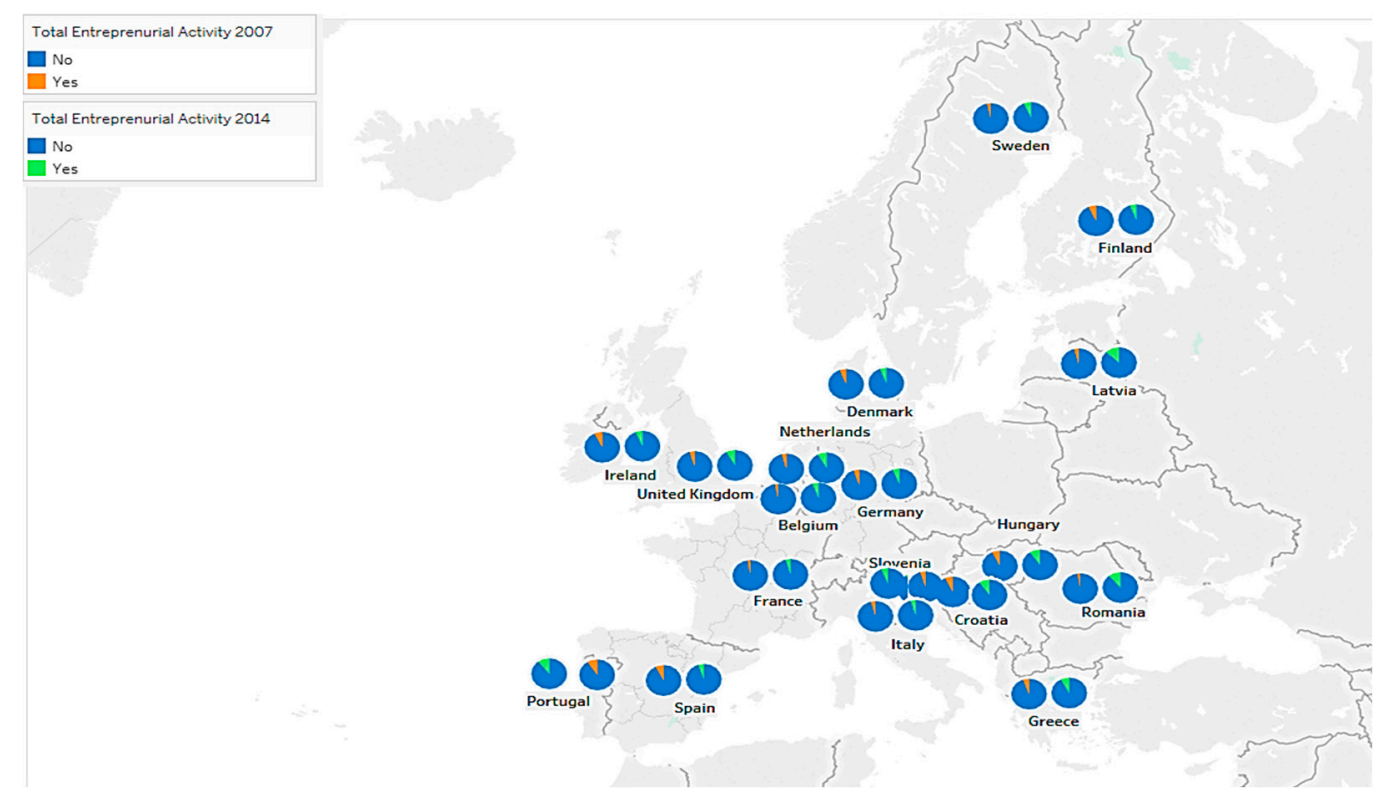

Figure 1. Sample distribution of involvement in entrepreneurial activities, 2007 and 2014.

Opportunity perception $\left(r_{2007}=0.129\right.$ and $\left.r_{2014}=0.114\right)$, self-confidence in their own skills $\left(r_{2007}=0.232\right.$ and $\left.r_{2014}=0.220\right)$, and networking $\left(r_{2007}=0.145\right.$ and $\left.r_{2014}=0.193\right)$ positively and significantly relate to entrepreneurial activities. As expected, fear of failure $\left(r_{2007}=-0.081\right.$ and $\left.r_{2014}=-0.089\right)$ negatively relates to our dependent variable. With respect to age and gender, both control variables negatively and significantly relate to entrepreneurial activities. Males and younger respondents are more likely to be involved in entrepreneurial activities than females, and older respondents have a higher tendency than younger respondents to engage in entrepreneurship (Table 3).

The analysis shows the results of several logistic regression analyses computed for 2007 and 2014, where we introduced different variables in subsequent steps of the logit models, following Liñán et al. [52] approach (Tables 4-7). In step 1, we included the control variables used in the analysis (namely, gender and age); in step 2, we added the individual characteristics (opportunity perception, fear of failure, self-confidence in their own skills and knowledge, and networking), and in step 3, the interaction effects. This approach is in agreement with the previous works on determinants of entrepreneurial intentions (see [52]), adapted though for measuring entrepreneurial activities. 
Table 3. Descriptive statistics and correlation coefficients $(n=18)$.

\begin{tabular}{|c|c|c|c|c|c|c|c|c|c|}
\hline & \multicolumn{9}{|c|}{ Year $=2007$} \\
\hline & Mean & SD & (1) & (2) & (3) & (4) & (5) & (6) & (7) \\
\hline (1) TEA & 0.05 & 0.227 & 1 & & & & & & \\
\hline (2) OPPORT & 0.38 & 0.484 & $0.129 * *$ & 1 & & & & & \\
\hline (3) FEARFAIL & 0.39 & 0.488 & $-0.081^{* *}$ & $-0.051^{* *}$ & 1 & & & & \\
\hline (4) SUSKILL & 0.48 & 0.500 & $0.232 * *$ & $0.187^{* *}$ & $-0.146^{* *}$ & 1 & & & \\
\hline (5) KNOWENT & 0.35 & 0.476 & $0.145^{* *}$ & $0.218^{* *}$ & $-0.030^{* *}$ & $0.232 * *$ & 1 & & \\
\hline (6) GENDER & 0.55 & 0.497 & $-0.077^{* *}$ & $-0.091 * *$ & $0.063^{* *}$ & $-0.161^{* *}$ & $-0.115^{* *}$ & 1 & \\
\hline \multirow[t]{3}{*}{ (7) AGE } & 43.34 & 13.476 & $-0.053 * *$ & $-0.057^{* *}$ & $-0.041^{* *}$ & -0.005 & $-0.152^{* *}$ & $0.020 * *$ & 1 \\
\hline & \multicolumn{9}{|c|}{ Year $=2014$} \\
\hline & Mean & SD & (1) & (2) & (3) & (4) & (5) & (6) & (7) \\
\hline (1) TEA & 0.06 & 0.245 & 1 & & & & & & \\
\hline (2) OPPORT & 0.29 & 0.456 & $0.114^{* *}$ & 1 & & & & & \\
\hline (3) FEARFAIL & 0.47 & 0.499 & $-0.089 * *$ & $-0.095^{* *}$ & 1 & & & & \\
\hline (4) SUSKILL & 0.44 & 0.496 & $0.220^{* *}$ & $0.091 * *$ & $-0.129 * *$ & 1 & & & \\
\hline (5) KNOWENT & 0.32 & 0.467 & 0.193 ** & $0.167^{* *}$ & $-0.051 * *$ & $0.223 * *$ & 1 & & \\
\hline (6) GENDER & 0.49 & 0.500 & $-0.069^{* *}$ & $-0.067^{* *}$ & $0.088^{* *}$ & $-0.135^{* *}$ & $-0.069 * *$ & 1 & \\
\hline (7) AGE & 43.17 & 13.775 & $-0.054^{* *}$ & $-0.054^{* *}$ & $-0.037^{* *}$ & $0.020 * *$ & $-0.096^{* *}$ & $0.022 * *$ & 1 \\
\hline
\end{tabular}

Tables 4-7 present the regression coefficients, significance level, exponential ratio, and Ward statistics, shown for each independent and control variable included in the study, as well as for the terms of interaction. As we mentioned previously, we used data retrieved from the Adult Population Survey, Global Entrepreneurship Monitor (GEM) annual survey for 2007 and 2014 and a total of 18 European countries.

Three logistic regression analyses were computed for 2007 for less developed economies to estimate the influence of individual characteristics on TEA.

Model (1) presents the control variables used in the analysis. The results reveal that gender and age show a significant and negative influence on early stage entrepreneurial activity. The negative effect of gender suggest that men are more likely to engage in early-stage entrepreneurial activities than women. Similarly, the age control variable showed a negative effect on the dependent variable, indicating that younger individuals have a higher likelihood of engaging in TEA than older respondents.

Model (2) introduces the main effects of perceptual factors (Table 4). In model (2) self-confidence has the highest odds ratio (8.781), suggesting that this factor has the greatest influence on the likelihood of engaging in early-stage entrepreneurial activity. This indicates that individuals who are confident in their own abilities, skills and knowledge have a higher propensity to engage in TEA than the rest of the population. A similar effect on TEA had the scores for networking, taking into consideration the constant variation of the other variables included in the model. The odds ratio was 1.504 for an additional unit to the score of networking when opportunity perception, self-confidence and fear of failure remain constant. The opportunity perception has a positive and significant effect on TEA, suggesting that respondents who perceive entrepreneurial opportunities were more likely to engage in early-stage entrepreneurial activities (Table 4). The probability to engage in TEA increases when the score for opportunity perception increases by one unit and the scores for fear of failure, self-confidence and networking remain constant. The odds ratio was 1.478 for an additional unit to the score of opportunity perception when the scores for fear of failure, self-confidence and networking remain constant. On the other hand, perceiving a higher risk of failure contributes to the decreasing entrepreneurial activities. The negative sign $(\beta=-0.338, p<0.01)$ indicates that the greater the fear of failure, the less likely to engage in entrepreneurial activity. 
Table 4. Coefficients of logit regressions measuring the determinants of early-stage entrepreneurial activity (2007).

\begin{tabular}{|c|c|c|c|c|c|c|c|c|c|}
\hline \multirow{3}{*}{ VARIABLE } & \multicolumn{9}{|c|}{ G1-2007 } \\
\hline & \multicolumn{3}{|c|}{ (1) } & \multicolumn{3}{|c|}{ (2) } & \multicolumn{3}{|c|}{ (3) } \\
\hline & $\beta$ & $\operatorname{Exp}(\beta)$ & Wald & $\beta$ & $\operatorname{Exp}(\beta)$ & Wald & $\beta$ & $\operatorname{Exp}(\beta)$ & Wald \\
\hline CONSTANT & $\begin{array}{c}-1.868^{* * * *} \\
(0.000)\end{array}$ & 0.154 & 1327.347 & $\begin{array}{c}-3.637^{* * * * *} \\
(0.000)\end{array}$ & 0.026 & 1278.038 & -3.548 & 0.029 & 906.380 \\
\hline \multicolumn{10}{|l|}{$\begin{array}{l}\text { CONTROL } \\
\text { VARIABLES }\end{array}$} \\
\hline GENDER & $\begin{array}{c}-0.168^{* * * *} \\
(0.000)\end{array}$ & 0.845 & 112.277 & $\begin{array}{c}-0.292 * * * * \\
(0.000)\end{array}$ & 0.747 & 35.664 & $\begin{array}{c}-0.497^{* * * *} \\
(0.002)\end{array}$ & 0.608 & 9.237 \\
\hline$A G E$ & $\begin{array}{c}-0.566^{* * * *} \\
(0.000)\end{array}$ & 0.568 & 191.057 & $\begin{array}{c}-0.146^{* * * * *} \\
(0.000)\end{array}$ & 0.864 & 54.135 & $\begin{array}{c}-0.145^{* * * *} \\
(0.000)\end{array}$ & 0.865 & 53.492 \\
\hline \multicolumn{10}{|l|}{$\begin{array}{l}\text { PERCEPTUAL } \\
\text { FACTORS }\end{array}$} \\
\hline OPPORT & & & & $\begin{array}{c}0.391^{* * * *} \\
(0.000)\end{array}$ & 1.478 & 66.250 & $\begin{array}{c}0.393^{* * * *} \\
(0.000)\end{array}$ & 1.481 & 41.877 \\
\hline FEARFAIL & & & & $\begin{array}{c}-0.338^{* * * *} \\
(0.000)\end{array}$ & 0.713 & 44.276 & $\begin{array}{c}-0.270 * * * * \\
(0.000)\end{array}$ & 0.763 & 17.377 \\
\hline SUSKILL & & & & $\begin{array}{c}2.173^{* * * * *} \\
(0.000)\end{array}$ & 8.781 & 781.184 & $\begin{array}{c}2.081^{* * * * *} \\
(0.000)\end{array}$ & 8.015 & 434.188 \\
\hline KNOWENT & & & & $\begin{array}{c}0.408^{* * * *} \\
(0.000)\end{array}$ & 1.504 & 67.183 & $\begin{array}{c}0.359^{* * * *} \\
(0.000)\end{array}$ & 1.432 & 32.219 \\
\hline \multicolumn{10}{|l|}{$\begin{array}{l}\text { INTERACTION } \\
\text { TERMS }\end{array}$} \\
\hline $\begin{array}{l}\text { OPPORT } \times \\
\text { GENDER }\end{array}$ & & & & & & & $\begin{array}{l}-0.006 \\
(0.949)\end{array}$ & 41.877 & 0.004 \\
\hline $\begin{array}{c}\text { FEARFAIL } \times \\
\text { GENDER }\end{array}$ & & & & & & & $\begin{array}{c}-0.175^{* *} \\
(0.094)\end{array}$ & 17.377 & 2.799 \\
\hline $\begin{array}{l}\text { SUSKILL } \times \\
\text { GENDER }\end{array}$ & & & & & & & $\begin{array}{c}0.216 \\
(0.175)\end{array}$ & 32.219 & 1.841 \\
\hline $\begin{array}{c}\text { KNOWENT } \times \\
\text { GENDER }\end{array}$ & & & & & & & $\begin{array}{c}0.126 \\
(0.215)\end{array}$ & 434.188 & 1.540 \\
\hline
\end{tabular}

Source: our own calculations. Dependent variable: probability of involvement in entrepreneurial activities (TEA). Standard errors in parentheses. ${ }^{* * * *} p<0.01 ; * * * p<0.05 ; * *<0.10$; ${ }^{*} p<0.15$. 
Table 5. Coefficients of logit regressions measuring the determinants of early-stage entrepreneurial activity (2007).

\begin{tabular}{|c|c|c|c|c|c|c|c|c|c|}
\hline \multirow{3}{*}{ VARIABLE } & \multicolumn{9}{|c|}{ G2-2007 } \\
\hline & \multicolumn{3}{|c|}{ (4) } & \multicolumn{3}{|c|}{ (5) } & \multicolumn{3}{|c|}{ (6) } \\
\hline & $\beta$ & $\operatorname{Exp}(\beta)$ & Wald & $\beta$ & $\operatorname{Exp}(\beta)$ & Wald & $\beta$ & $\operatorname{Exp}(\beta)$ & Wald \\
\hline CONSTANT & $\begin{array}{c}-2.084^{* * * *} \\
(0.000)\end{array}$ & 0.124 & 1521.405 & $\begin{array}{c}-3.731 * * * * \\
(0.000)\end{array}$ & 0.024 & 1583.537 & $\begin{array}{c}-3.551^{* * * *} \\
(0.000)\end{array}$ & 0.029 & 994.163 \\
\hline \multicolumn{10}{|l|}{$\begin{array}{c}\text { CONTROL } \\
\text { VARIABLES }\end{array}$} \\
\hline GENDER & $\begin{array}{c}-0.719^{* * * *} \\
(0.000)\end{array}$ & 0.487 & 349.683 & $\begin{array}{c}-0.170 * * * * \\
(0.000)\end{array}$ & 0.844 & 14.456 & $\begin{array}{c}-0.532 * * * * \\
(0.000)\end{array}$ & 0.588 & 15.055 \\
\hline$A G E$ & $\begin{array}{c}-0.166^{* * * *} \\
(0.000)\end{array}$ & 0.847 & 120.579 & $\begin{array}{c}-0.153^{* * * *} \\
(0.000)\end{array}$ & 0.858 & 68.586 & $\begin{array}{c}-0.151^{* * * *} \\
(0.000)\end{array}$ & 0.860 & 67.027 \\
\hline \multicolumn{10}{|l|}{$\begin{array}{l}\text { PERCEPTUAL } \\
\text { FACTORS }\end{array}$} \\
\hline OPPORT & & & & $\begin{array}{c}0.659 * * * * \\
(0.000)\end{array}$ & 1.933 & 206.914 & $\begin{array}{c}0.640^{* * * * *} \\
(0.000)\end{array}$ & 1.896 & 112.337 \\
\hline FEARFAIL & & & & $\begin{array}{c}-0.485^{* * * *} \\
(0.000)\end{array}$ & 0.616 & 80.015 & $\begin{array}{c}-0.563^{* * * *} \\
(0.000)\end{array}$ & 0.569 & 57.045 \\
\hline SUSKILL & & & & $\begin{array}{c}1.880^{* * * * *} \\
(0.000)\end{array}$ & 6.551 & 806.655 & $\begin{array}{c}1.758^{* * * *} \\
(0.000)\end{array}$ & 5.800 & 349.545 \\
\hline KNOWENT & & & & $\begin{array}{c}0.641 \text { **** } \\
(0.000)\end{array}$ & 1.898 & 199.660 & $\begin{array}{c}0.559^{* * * * *} \\
(0.000)\end{array}$ & 1.750 & 89.308 \\
\hline \multicolumn{10}{|c|}{$\begin{array}{l}\text { INTERACTION } \\
\text { TERMS }\end{array}$} \\
\hline $\begin{array}{c}\text { OPPORT } \times \\
\text { GENDER }\end{array}$ & & & & & & & $\begin{array}{c}0.041 \\
(0.659)\end{array}$ & 1.042 & .194 \\
\hline $\begin{array}{c}\text { FEARFAIL } \times \\
\text { GENDER }\end{array}$ & & & & & & & $\begin{array}{l}0.167^{*} \\
(0.124)\end{array}$ & 1.182 & 2.368 \\
\hline $\begin{array}{c}\text { SUSKILL } \times \\
\text { GENDER }\end{array}$ & & & & & & & $\begin{array}{l}0.224^{* *} \\
(0.088)\end{array}$ & 1.252 & 2.902 \\
\hline $\begin{array}{l}\text { KNOWENT } \times \\
\text { GENDER }\end{array}$ & & & & & & & $\begin{array}{c}0.192^{* * *} \\
(0.035)\end{array}$ & 1.211 & 4.444 \\
\hline
\end{tabular}

Source: our own calculations. Dependent variable: Probability of involvement in entrepreneurial activities (TEA). Standard errors in parentheses. ${ }^{* * * *} p<0.01 ; * * * p<0.05 ; * *<0.10$; ${ }^{*} p<0.15$. 
Table 6. Coefficients of logit regressions measuring the determinants of early-stage entrepreneurial activity (2014).

\begin{tabular}{|c|c|c|c|c|c|c|c|c|c|}
\hline \multirow{3}{*}{ VARIABLE } & \multicolumn{9}{|c|}{ G1-2014 } \\
\hline & \multicolumn{3}{|c|}{ (7) } & \multicolumn{3}{|c|}{ (8) } & \multicolumn{3}{|c|}{ (9) } \\
\hline & $\beta$ & $\operatorname{Exp}(\beta)$ & Wald & $\beta$ & $\operatorname{Exp}(\beta)$ & Wald & $\beta$ & $\operatorname{Exp}(\beta)$ & Wald \\
\hline CONSTANT & $\begin{array}{c}-1.969^{* * * *} \\
(0.000)\end{array}$ & 0.140 & 1156.125 & $\begin{array}{c}-3.786^{* * * * *} \\
(0.000)\end{array}$ & 0.023 & 1451.394 & $\begin{array}{c}-3.704^{* * * *} \\
(0.000)\end{array}$ & 0.025 & 1042.861 \\
\hline \multicolumn{10}{|l|}{$\begin{array}{l}\text { CONTROL } \\
\text { VARIABLES }\end{array}$} \\
\hline GENDER & $\begin{array}{c}-0.508^{* * * *} \\
(0.000)\end{array}$ & 0.602 & 126.292 & $\begin{array}{c}-0.245^{* * * * *} \\
(0.000)\end{array}$ & 0.783 & 22.804 & $\begin{array}{c}-0.449 * * * * \\
(0.003)\end{array}$ & 0.638 & 8.769 \\
\hline$A G E$ & $\begin{array}{c}-0.174^{* * * *} \\
(0.000)\end{array}$ & 0.841 & 97.863 & $\begin{array}{c}-0.166^{* * * * *} \\
(0.000)\end{array}$ & 0.847 & 61.907 & $\begin{array}{c}-0.165^{* * * *} \\
(0.000)\end{array}$ & 0.848 & 61.449 \\
\hline \multicolumn{10}{|l|}{$\begin{array}{l}\text { PERCEPTUAL } \\
\text { FACTORS }\end{array}$} \\
\hline OPPORT & & & & $\begin{array}{c}0.659^{* * * *} \\
(0.000)\end{array}$ & 1.489 & 1.631 & $\begin{array}{c}0.446^{* * * *} \\
(0.000)\end{array}$ & 1.562 & 46.432 \\
\hline FEARFAIL & & & & $\begin{array}{c}-0.381^{* * * * *} \\
(0.000)\end{array}$ & 0.683 & 53.475 & $\begin{array}{c}-0.372 * * * * \\
(0.000)\end{array}$ & 0.690 & 30.838 \\
\hline SUSKILL & & & & $\begin{array}{c}1.755^{* * * * *} \\
(0.000)\end{array}$ & 5.784 & 627.046 & $\begin{array}{c}1.736^{* * * * *} \\
(0.000)\end{array}$ & 5.676 & 353.557 \\
\hline KNOWENT & & & & $\begin{array}{c}1.054^{* * * *} \\
(0.000)\end{array}$ & 2.869 & 401.628 & $\begin{array}{c}0.973^{* * * *} \\
(0.000)\end{array}$ & 2.645 & 212.752 \\
\hline \multicolumn{10}{|c|}{$\begin{array}{l}\text { INTERACTION } \\
\text { TERMS }\end{array}$} \\
\hline $\begin{array}{l}\text { OPPORT } \times \\
\text { GENDER }\end{array}$ & & & & & & & $\begin{array}{c}0.129 \\
(0.236)\end{array}$ & 1.137 & 1.402 \\
\hline $\begin{array}{l}\text { FEARFAIL } \times \\
\text { GENDER }\end{array}$ & & & & & & & $\begin{array}{l}-0.025 \\
(0.818)\end{array}$ & 0.976 & 0.053 \\
\hline $\begin{array}{l}\text { SUSKILL } \times \\
\text { GENDER }\end{array}$ & & & & & & & $\begin{array}{c}0.038 \\
(0.788)\end{array}$ & 1.039 & 0.073 \\
\hline $\begin{array}{l}\text { KNOWENT } \times \\
\text { GENDER }\end{array}$ & & & & & & & $\begin{array}{c}0.214^{* * *} \\
(0.048)\end{array}$ & 1.239 & 3.913 \\
\hline
\end{tabular}

Source: our own calculations. Dependent variable: probability of involvement in entrepreneurial activities (TEA). Standard errors in parentheses. ${ }^{* * * *} p<0.01 ; * * * p<0.05 ; * *<0.10$; ${ }^{*} p<0.15$. 
Table 7. Coefficients of logit regressions measuring the determinants of early-stage entrepreneurial activity (2014).

\begin{tabular}{|c|c|c|c|c|c|c|c|c|c|}
\hline \multirow{3}{*}{ VARIABLE } & \multicolumn{9}{|c|}{ G2-2014 } \\
\hline & \multicolumn{3}{|c|}{ (10) } & \multicolumn{3}{|c|}{ (11) } & \multicolumn{3}{|c|}{ (12) } \\
\hline & $\beta$ & $\operatorname{Exp}(\beta)$ & Wald & $\beta$ & $\operatorname{Exp}(\beta)$ & Wald & $\beta$ & $\operatorname{Exp}(\beta)$ & Wald \\
\hline CONSTANT & $\begin{array}{l}-1.948^{* * * *} \\
(0.000)\end{array}$ & 0.143 & 806.882 & $\begin{array}{c}-3.586^{* * * * *} \\
(0.000)\end{array}$ & 0.028 & 929.639 & $\begin{array}{c}-3.553^{* * * * *} \\
(0.000)\end{array}$ & 0.029 & 664.839 \\
\hline \multicolumn{10}{|l|}{$\begin{array}{l}\text { CONTROL } \\
\text { VARIABLES }\end{array}$} \\
\hline GENDER & $\begin{array}{c}-0.662 * * * * \\
(0.000)\end{array}$ & 0.516 & 142.697 & $\begin{array}{c}-0.222 * * * * \\
(0.001)\end{array}$ & 0.801 & 11.616 & $\begin{array}{c}-0.307^{* *} \\
(0.091)\end{array}$ & 0.736 & 2.851 \\
\hline$A G E$ & $\begin{array}{c}-0.135^{* * * *} \\
(0.000)\end{array}$ & 0.873 & 44.508 & $\begin{array}{c}-0.207^{* * * * *} \\
(0.000)\end{array}$ & 0.813 & 68.150 & $\begin{array}{c}-0.207^{* * * *} \\
(0.000)\end{array}$ & 0.813 & 68.101 \\
\hline \multicolumn{10}{|l|}{$\begin{array}{l}\text { PERCEPTUAL } \\
\text { FACTORS }\end{array}$} \\
\hline OPPORT & & & & $\begin{array}{c}0.422 * * * * \\
(0.000)\end{array}$ & 1.524 & 43.016 & $\begin{array}{c}0.350 * * * * \\
(0.000)\end{array}$ & 1.419 & 19.005 \\
\hline FEARFAIL & & & & $\begin{array}{c}-0.747^{* * * * *} \\
(0.000)\end{array}$ & 0.474 & 108.123 & $\begin{array}{c}-0.737^{* * * * *} \\
(0.000)\end{array}$ & 0.479 & 62.851 \\
\hline SUSKILL & & & & $\begin{array}{l}1.919^{* * * * *} \\
(0.000)\end{array}$ & 6.816 & 523.951 & $\begin{array}{c}1.911^{* * * * *} \\
(0.000)\end{array}$ & 6.758 & 288.614 \\
\hline KNOWENT & & & & $\begin{array}{c}1.177^{* * * * *} \\
(0.000)\end{array}$ & 3.246 & 310.833 & $\begin{array}{l}1.199 * * * * \\
(0.000)\end{array}$ & 3.315 & 200.233 \\
\hline \multicolumn{10}{|c|}{$\begin{array}{l}\text { INTERACTION } \\
\text { TERMS }\end{array}$} \\
\hline $\begin{array}{c}\text { OPPORT } \times \\
\text { GENDER }\end{array}$ & & & & & & & $\begin{array}{l}0.197 * \\
(0.141)\end{array}$ & 1.218 & 2.162 \\
\hline $\begin{array}{l}\text { FEARFAIL } \times \\
\text { GENDER }\end{array}$ & & & & & & & $\begin{array}{l}-0.019 \\
(0.897)\end{array}$ & 0.981 & 0.017 \\
\hline $\begin{array}{l}\text { SUSKILL } \times \\
\text { GENDER }\end{array}$ & & & & & & & $\begin{array}{c}0.016 \\
(0.925)\end{array}$ & 1.016 & 0.009 \\
\hline $\begin{array}{l}\text { KNOWENT } \times \\
\text { GENDER }\end{array}$ & & & & & & & $\begin{array}{l}-0.060 \\
(0.662)\end{array}$ & 0.942 & 0.191 \\
\hline
\end{tabular}

Source: our own calculations. Dependent variable: probability of involvement in entrepreneurial activities (TEA). Standard errors in parentheses. ${ }^{* * * *} p<0.001 ; * * * p<0.005 ; * * p<0.10$; ${ }^{*} p<0.15$. 
Model (3) tests the interaction effects between opportunity perception and gender, fear of failure, self-confidence, and networking, respectively. Using the variable of gender as a moderator, we can see if the influence of these variables differs between males and females. The interaction effect reveals that gender has a significant influence on the interaction with the fear of failure. The odds ratio was 17.377 when the score of fear of failure increases by one unit and gender is 1 . We could not find any significant interaction effects between other perceptual factors and gender.

Other three logistic regression analyses were computed for 2007 for highly developed economies (G2). Similarly, model (4) presents the control variables for the second group of countries. The results show that both men and young people have a higher inclination towards entrepreneurial activity. Model (5) introduces the main effects of the independent variables for the second group of countries. The findings show that unlike G1, in G2 self-efficacy and opportunity perception have the highest odds ratios (6.551, and 1.933, respectively). Self-confidence is positively associated with the probability to engage in early-stage entrepreneurial activity, suggesting that the knowledge, skills and experience required for starting a new business has a positive effect on TEA. The odds ratio was 1.933 for an additional unit to the score of opportunity perception when the scores for fear of failure, self-confidence and networking remain constant, suggesting that individuals who recognize opportunities are 1.933 times more likely to engage in TEA than those who do not. Similarly, having a good entrepreneurial network increases the likelihood of engaging in entrepreneurial activity $(p<0.01$; odds ratio 1.898). A negative effect on the likelihood of engaging in entrepreneurial activity appeared from the scores for fear of failure $(p<0.01)$, showing an inverse relationship between this individual characteristic and the propensity to engage in TEA (Table 5 ).

Model (6) showed that all the interactions between independent variables, namely; opportunity perception, fear of failure, self-confidence, networking, and gender (G2). The first interaction showed a positive but insignificant influence on the probability to engage in entrepreneurial activity. The following interactions have a significant effect, revealing differences in individual perceptions between males and females. The interaction effect reveals that the increase by one unit of the variable self-confidence and the fact that gender is 1 , while all the other variables remain constant, found an increase in the probability of involving TEA. We found significant interactions between gender and fear of failure with an odds ratio of 1.182, and networking and gender with an odds ratio of 1.211.

Table 6 replicated the analysis to show varying effects of individual characteristics on TEA across another time period. Gender shows a consistently negative and significant effect for all groups and periods of time considered. Age recorded similar results, which was negatively and statistically significant in both periods, validating Hypotheses 1 and 2.

In terms of perceptual variables, self-confidence shows a consistently positive and significant effect across the two time periods and groups. The variable has the highest odds ratio in the logistic regression equations for all the models developed (recording the highest odds ratio for G1 in 2007 oddsratio $_{2007 / G 1}=8.781$ and oddsratio $2014 / G 1=5.784$ in 2014; oddsratio $_{2007 / G 2}=6.551$ in 2007 and oddsratio $2014 / G 2=6.816$ in 2014, for G2, respectively), thereby, validating Hypothesis 5. Opportunity perception showed a positive and significant effect on TEA for all groups of countries in both 2007 and 2014, suggesting that individuals who perceived entrepreneurial opportunities are more likely to engage in early-stage entrepreneurial activities. The odds ratios for opportunity perception is lower when compared to self-efficacy $\left(\right.$ oddsratio $_{2007 / G 1}=1.478$; oddsratio $_{2007 / G 2}=1.933 ;$ oddsratio $_{2014 / G 1}=1.489$, and oddsratio $2014 / \mathrm{G} 2=1.524)$. The coefficient shows that opportunity perception is a strong predictor for developed countries in 2007, but its importance decreased in 2014. However, this variable positively and significantly influenced TEA for both groups of countries, validating Hypothesis 3 (Tables 4-7).

As we can see, fear of failure maintains the negative sign in follow-up models, showing that this variable contributes to the decrease in the probability of engagement in TEA. Thus, the hypothesis according to which the fear of failure is positively and significantly associated with the early-stage entrepreneurial activity is rejected (H4). For the individuals from G1, the odds ratio was not that high (oddsratio $_{2007}=0.713$ and oddsratio $2014=0.683$ ), indicating that this perceptual variable had the lowest 
effect on the likelihood of involvement in TEA in both periods. Although, the odds ratio increased in 2014 for G2, it still remained the lowest among the individual-perception factors (see models (8), (9), (11) and (12) (Table 7). In 2014 the odds ratio for networking almost doubled, suggesting the strong effect of this variable on the propensity to engage in early-stage entrepreneurial activity (oddsratio ${ }_{2007 / G 1}=1.504$ to oddsratio $2014 / \mathrm{G} 1=2.869 ;$ oddsratio $_{2007 / G 2}=1.898$ to oddsratio $2014 / \mathrm{G} 2=3.246$ ). In 2007, this variable alongside self-confidence was one of the strongest predictors of TEA for countries from G1, and in 2014 for both groups of countries, showing that networking exerts a positive and significant influence on early-stage entrepreneurial activity, validating H6. The only significant interactions for G1 and G2 are between networking and gender (odds ratio of 1.239) and opportunity perception and gender (odds ratio of 1.218) (Tables 4-7). For highly developed economies, we could not find any other interaction effects between other independent variables and gender (Tables 6 and 7). The odds ratios and standardized coefficients show that for less developed countries from G1, self-confidence and networking were the strongest predictors both in 2007 and 20014. In 2007, for high developed economies belonging to G2 the strongest predictors were opportunity perception and self-confidence. However, in 2014 the highest odds ratios were obtained for self-confidence and networking (Tables 4-7).

Table 8 The goodness-of-fit statistics indicates the results for Omnibus Test, Cox \& Snell $R^{2}$, Nagelkerke $R^{2}$, and -2 Log Likelihood.

Table 8. Goodness-of-fit statistics.

\begin{tabular}{ccccc}
\hline & & Model (1) & Model (2) & Model (3) \\
\hline Omnibus Tests (significance level) & & 0.000 & 0.000 & 0.000 \\
Cox and Snell $R^{2}$ & 2007 (G1) & 0.008 & 0.080 & 0.081 \\
Nagelkerke $R^{2}$ & 0.020 & 0.180 & 0.180 \\
-2 Log likelihood & $19,643.181$ & $12,535.811$ & $12,528.387$ \\
\hline Omnibus Tests (significance level) & & Model (4) & Model (5) & Model (6) \\
Cox and Snell $R^{2}$ & 0.000 & 0.000 & 0.000 \\
Nagelkerke $R^{2}$ & 2007 (G2) & 0.008 & 0.079 & 0.080 \\
-2 Log likelihood & 0.024 & 0.187 & 0.188 \\
\hline & $23,133.556$ & $15,005.636$ & $14,994.777$ \\
\hline Omnibus Tests (significance level) & & Model (7) & Model (8) & Model (9) \\
Cox and Snell $R^{2}$ & 0.000 & 0.000 & 0.000 \\
Nagelkerke $R^{2}$ & $2014(\mathrm{G} 1)$ & 0.006 & 0.070 & 0.070 \\
-2 Log likelihood & 0.017 & 0.183 & 0.184 \\
\hline & & $16,526.183$ & $12,000.020$ & $11,993.455$ \\
\hline Omnibus Tests (significance level) & & Model (10) & Model (11) & Model (12) \\
\hline Cox and Snell $R^{2}$ & 2014 (G2) & 0.000 & 0.000 & 0.000 \\
Nagelkerke $R^{2}$ & & 0.022 & 0.102 & 0.102 \\
-2 Log likelihood & 11006.386 & 7336.323 & 7334.051 \\
\hline
\end{tabular}

Source: our own calculations.

The Omnibus tests of model coefficients are significant $(p<0.05)$, confirming the causal relationship of the proposed logit models and acceptance of the hypothesis that $\beta$ coefficients are different from zero. Although, Cox \& Snell $R^{2}$, Nagelkerke $R^{2}$ indicate that the variables considered explain only a small fraction of the variance in entrepreneurial activity, their values increased from one model to the other.

-2 Log likelihood values decrease from Model 1 to 3, 4-6, 7-9, and 10-12 providing additional support for the adequacy of the models. 


\section{Conclusions and Study Limitations}

There are numerous theoretical and empirical approaches investigating the importance of entrepreneurship in promoting the development process [53,54]. Different approaches to entrepreneurship mainly present three sets of research questions: Why, how, when or where some people and not others discover and exploit different entrepreneurial opportunities [12]. In fact, the cognitive framework attempts to explain the main aspects of the discovery-exploitation process, not only at an individual level, but also at an aggregate level [52]. Starting from this perspective, our main focus was on understanding the role of different perceptual factors on the probability to engage in entrepreneurial activities.

The study used logit regression models to estimate the probability that, individuals belonging to a specific group have a high susceptibility to several cognitive biases. We chose the logit regression analysis as the vast majority of variables were dichotomous, including our dependent variable. This type of analysis allowed us to estimate the effect of several independent variables on the probability of engagement in entrepreneurial activities. Specifically, the main objective of the paper is to examine the effects of demographic variables (gender and age), perceptual factors (capability to identify opportunity, having skills, knowledge and experience to start up businesses, fear of failing, and knowing other entrepreneurs), and the interaction effects between them and gender on the likelihood of engaging in entrepreneurial activities across eighteen European Union member states, based on the statistics gathered by the GEM (individual data).

Moreover, the literature shows that entrepreneurial activity determinants are sensitive to time and country GDP $[5,18,19]$. Starting from this theoretical framework, we consider that entrepreneurship research must focus on how different periods may shape the pattern of relationships between variables, in different contexts. To that aim, our study examines two different moments in time, namely 2007 and 2014, in order to capture the fluctuations in entrepreneurial activities and the effects of different perceptual factors, in less and highly developed European member states. We measured the level of entrepreneurial activity using the total early-stage entrepreneurial activity (TEA) as a proxy, including individuals aged between 18 to 64 , who were either actively trying to start a new business, or managing a business that was less than three-and-a half years old. Our results show that across the countries analysed, TEA tends to be the highest among factor-driven economies and declines in economies with higher GDP per capita. From the sample analysed, the mean average of TEA for less developed economies (G1) was 5.85\% in 2007 and 7.19\% in 2014, while the average mean of TEA was 4.53 in 2007 and $6.74 \%$ in 2014 for economies with higher GDP per capita (G2).

In the empirical analysis, we followed Liñán et al. [52] approach, however adapted for measuring entrepreneurial activities. In subsequent steps, we first included the control variables in the analysis, then we added the individual characteristics (opportunity perception, fear of failure, self-confidence in their own skills, knowledge, and networking), and in the last step, the interaction effects between perceptual factors and gender.

In agreement with our hypotheses, the results reveal that gender is an important determinant which affects the probability to engage in entrepreneurial activities, men being more inclined to engage in entrepreneurship than females. Similarly, other studies reached to the same outcome, i.e., the constant differences between men and women in developing entrepreneurial activity are due to gender characterisation [5,6,55,56]. For instance, according to Brush et al. [57] gender parity in perceived capabilities and economic participation significantly influence the relative parity to early-stage entrepreneurship. Other authors' studies show similar results. In fact, Özdemir and Karadeniz [6] demonstrate that, men with a higher income and education level, who are confident in themselves, have the ability to identify business opportunities, and are in contact with other entrepreneurs are twice more likely to engage in entrepreneurial activities than women.

Further findings are also consistent with the literature, consequently younger individuals are more likely to engage in entrepreneurial activities than older people [5,35]. The study conducted by Colovic at al. [58] shows that third-age entrepreneurs tend to lag behind their younger counter 
parts in technology adoption and innovation. Further evidence underlines that entrepreneurship represents the main driver for development and economic recovery and is generally associated with young individuals [59].

Besides gender and age, the analysis shows the importance of perceptual factors for entrepreneurial activity in EU-18 member states. The results show that three perceptual factors, namely self-confidence, opportunity perception, and networking have a positive and significant influence on early-stage entrepreneurial activities in both, groups of countries and time periods. As anticipated, the fear of failure has a negative and significant effect on entrepreneurial activity. These results underline that, despite the recent economic and financial crisis, individuals who possess these attributes are more likely to engage in new venture creation.

We can see that in 2007, the strongest determinants were self-confidence and networking for less advanced economies, while opportunity recognition and self-confidence had the highest odds ratio for more developed economies. In 2014, although opportunity recognition remained an important determinant for TEA, this influence was not as high as anticipated. This might be the case that individuals with high early-stage entrepreneurial activity engagement perceived the recognition of opportunities as a normal situation. As Liñán et al. [52] stated, "it is possible too that the presence of cognitive biases is exerting an influence on perceptions about economic opportunities". These results are in agreement with other author's findings, who consider that these entrepreneurial attributes are important assets when starting a business $[5,8,13,46]$. On the other hand, the analysis on fear of failure reveals a negative influence on early-stage entrepreneurial activities, showing that individuals who perceive this negative emotion resulting from the perception of different threats are less likely to engage in early entrepreneurial activities. We validated these results for both groups of countries and time periods. The findings are in agreement with previous studies that consider fear of failure is a constraining factor for venture creation [10].

In this study we also tested the interaction effects between opportunity perception and gender, fear of failure, self-confidence, and networking, respectively, for both groups and time periods. Using the variable gender as a moderator, we show that the influence of these variables differs between males and females. In 2007, the interaction effects revealed that, for less developed economies, gender had a significant influence on the interaction with the fear of failure. The odds ratio was 17.377 when the score of fear of failure increased by one unit and gender was 1 . We did not find any interaction effect between other independent variables and gender. For high developed economies, the interactions showed a positive and significant effect between three perceptual factors and gender. The interaction effect reveals that the increase by one unit of the variable self-confidence and the fact that gender is 1 , while all the other variables remain constant, determined an increase in the probability to involve in TEA. We found significant interactions between gender and fear of failure with an odds ratio of 1.182 and networking and gender with an odds ratio of 1.211. In 2014, the only significant interaction for both groups of countries are between networking and gender (odds ratio of 1.239), and opportunity perception and gender (odds ratio of 1.218).

We evaluated the relative importance of predictors in logistic models using fully standardised logistic regression coefficient calculated using Equations (3) and (4) [22,60].

For our analysis, although we cannot directly calculate the standard deviation for the observed values of logit (TEA), we estimated the standard deviation indirectly using the predicted values of logit (TEA) and the explained variance, $R^{2}$ [60]. In order to rank the magnitude of the influence of the predictors on the dependent variable, we applied Menard [22] and Menard [60] methodology to estimate fully standardized logistic regression coefficients. According to the Equations (3) and (4), we estimated the standard logistic regression coefficients (Table 9). Using the data from the estimates we are able to predict whether a dichotomous predictor (TEA) is more or less strongly related to the outcome. 
Table 9. Fully standardized coefficients for logit models $\left(b_{M}^{*}\right)$.

\begin{tabular}{|c|c|c|c|c|c|c|}
\hline \multirow{2}{*}{$\begin{array}{c}\text { Standardized } \\
\text { Predictors }\end{array}$} & \multicolumn{3}{|c|}{ G1-2007 } & \multicolumn{3}{|c|}{ G2-2007 } \\
\hline & (1) & (2) & (3) & (4) & (5) & (6) \\
\hline gender & -0.020 & -0.032 & -0.054 & -0.076 & -0.019 & -0.060 \\
\hline age & -0.172 & -0.040 & -0.039 & -0.043 & -0.043 & -0.042 \\
\hline opport & & 0.041 & 0.041 & & 0.074 & 0.071 \\
\hline fearfail & & -0.037 & -0.029 & & -0.053 & -0.060 \\
\hline suskill & & 0.240 & 0.225 & & 0.216 & 0.200 \\
\hline knowent & & 0.044 & 0.038 & & 0.069 & 0.059 \\
\hline opportxgender & & & 0.000 & & & 0.003 \\
\hline fearfailxgender & & & -0.016 & & & 0.014 \\
\hline suskillxgender & & & 0.019 & & & 0.020 \\
\hline knowentxgender & & & 0.010 & & & 0.014 \\
\hline Standardized & \multicolumn{3}{|c|}{ G1-2014 } & \multicolumn{3}{|c|}{ G2-2014 } \\
\hline Predictors & (7) & (8) & (9) & (10) & (11) & (12) \\
\hline gender & -0.057 & -0.029 & -0.052 & -0.080 & -0.029 & -0.040 \\
\hline age & -0.049 & -0.049 & -0.048 & -0.043 & -0.070 & -0.070 \\
\hline opport & & 0.065 & 0.043 & & 0.054 & 0.044 \\
\hline fearfail & & -0.045 & -0.043 & & -0.096 & -0.095 \\
\hline suskill & & 0.205 & 0.201 & & 0.242 & 0.240 \\
\hline knowent & & 0.117 & 0.107 & & 0.139 & 0.141 \\
\hline opportxgender & & & 0.008 & & & 0.019 \\
\hline fearfailxgender & & & -0.003 & & & -0.002 \\
\hline suskillxgender & & & 0.004 & & & 0.001 \\
\hline knowentxgender & & & 0.018 & & & -0.005 \\
\hline
\end{tabular}

Source: our own calculations.

When the analysis includes only the control variables, estimates show that in both groups and periods gender was the strongest predictor, followed by age (see (1), (4), (7) and (10), Table 7).

In 2007, in less and high developed countries, having skills, knowledge and experience to start up businesses have the strongest relationship with TEA, while gender has the weakest relationship with TEA. In less developed countries, knowing other entrepreneurs $\left(b_{M}^{*}=0.044\right)$ has the second importance in predicting entrepreneurial activity, followed by opportunity perception $\left(b_{M}^{*}=0.041\right)$, age $\left(b_{M}^{*}=0.040\right)$, and fear of failing $\left(b_{M}^{*}=-0.037\right)$. Contrary to the situation from G1 countries, in high developed countries the capability to identify opportunity $\left(b_{M}^{*}=0.074\right)$ has the second importance in predicting TEA, followed by knowing other entrepreneurs $\left(b_{M}^{*}=0.069\right)$, fear of failing $\left(b_{M}^{*}=-0.053\right)$ and age $\left(b_{M}^{*}=-0.043\right)$ (see (2) and (5), Table 9).

In subsequent models, we also added the interaction effects between individual attributes and gender. In 2007, in both groups, G1 and G2, self-confidence has the strongest relationship with TEA, while the standardized interaction between opportunity perception and gender has the weakest relationship with TEA. In less developed countries, gender $\left(b_{M}^{*}=-0.054\right)$ is the second important predictor of TEA, followed by perception of opportunities $\left(b_{M}^{*}=0.041\right)$, networking $\left(b_{M}^{*}=0.038\right)$, age $\left(b_{M}^{*}=-0.029\right)$, fear of failing $\left(b_{M}^{*}=-0.029\right)$, and the standardized interactions between gender and each of the variables having skills, knowledge and experience to start up businesses $\left(b_{M}^{*}=0.019\right)$, fear of failing $\left(b_{M}^{*}=-0.016\right)$ and networking $\left(b_{M}^{*}=0.010\right)$. Contrary to the situation from G1 countries, in G2 countries perception of opportunities $\left(b_{M}^{*}=0.071\right)$ has the second importance in predicting TEA, followed by gender $\left(b_{M}^{*}=-0.06\right)$, fear of failing $\left(b_{M}^{*}=-0.060\right)$, networking $\left(b_{M}^{*}=0.059\right)$, age $\left(b_{M}^{*}=-0.042\right)$, and the interactions between gender and each of the variables having skills, knowledge and experience to start up businesses $\left(b_{M}^{*}=0.020\right)$, networking $\left(b_{M}^{*}=0.015\right)$ and fear of failing $\left(b_{M}^{*}=0.014\right)$ (see (3) and (6), Table 9).

Similarly, in 2014, in both less and high developed countries, having skills, knowledge and experience to start up businesses had the strongest relationship with TEA. However, in both groups of countries, the second importance in predicting entrepreneurial activity was networking. In less developed countries, age $\left(b_{M}^{*}=-0.049\right)$ has the third importance in predicting TEA, followed by 
opportunity perception $\left(b_{M}^{*}=0.065\right)$, fear of failing $\left(b_{M}^{*}=-0.045\right)$ and gender $\left(b_{M}^{*}=-0.029\right)$. In high developed countries, fear of failure $\left(b_{M}^{*}=-0.096\right)$ ranked third in predicting entrepreneurial activities, followed by age $\left(b_{M}^{*}=-0.070\right)$, opportunity perception $\left(b_{M}^{*}=0.054\right)$ and gender $\left(b_{M}^{*}=-0.029\right)$ (see (8) and (11), Table 9). The following models included also the interactions effects for both groups. In 2014, for both groups of countries, having skills, knowledge and experience to start up businesses and networking had the strongest importance in predicting TEA. In 2014, for less developed economies, the follow up variables were gender $\left(b_{M}^{*}=-0.052\right)$, age $\left(b_{M}^{*}=-0.048\right)$, opportunity perception $\left(b_{M}^{*}=0.043\right)$, fear of failing $\left(b_{M}^{*}=-0.043\right)$ and the interactions between gender and each perceptual factor. For high developed economies, the third importance in predicting early-stage entrepreneurial activity was fear of failing $\left(b_{M}^{*}=-0.094\right)$, followed by age $\left(b_{M}^{*}=-0.070\right)$, then opportunity perception $\left(b_{M}^{*}=0.044\right)$, gender $\left(b_{M}^{*}=-0.039\right)$, and the interactions between gender and each perceptual factor (see (9) and (12), Table 9).

Evidence suggests that a high level of economic development (e.g., high national income per capita) exerts a positive influence on the creation of new business [61]. Nevertheless, according to our findings and based on the data provided by GEM, we found that less developed countries recorded higher rates of new businesses than most high developed economies. A possible explanation for this scenario is the fact that in less developed economies, individuals engage in entrepreneurial activities as a necessity (lack of jobs, high unemployment rates). As Carlsson [62] stated, the start-up rate increased during the seventies and eighties, only after unemployment becomes a serious issue.

Our analysis shows that in both less and high developed economies, most individuals start an entrepreneurial activity because of self-confidence and networking. Clearly, one's cognitive perception about skills, knowledge and abilities has an important effect on the efforts undertaken and how to persist in these efforts when potential obstacles arise. Individuals are more likely to engage in venture creation and choose entrepreneurship as a career path if they have the confidence to be more successful in their choice, based on their skills and knowledge [63]. Similarly, an individual's position in a social structure may influence the attitudes, behaviour and outcomes of the individuals occupying those positions. Translated into entrepreneurship, this implies that one's personal and organisational network may influence the actor's propensity to engage in venture creation. Outcomes show that for both groups of countries, networking have mostly the second strongest impact on an individual's decision to engage in entrepreneurial activity. In other words, networking represents one of the most important drives in choosing entrepreneurship as a career path. It is clear that entrepreneurs need to establish connections to identify an opportunity and find the necessary resources to begin operations [64].

Self-confidence and networking, other two perceptual factors, have an important impact on the entrepreneurial activity. Opportunity perception implies not only individuals' opportunity recognition, but also their fit, i.e., the individual opportunity nexus [29]. Opportunities exist only when people perceive them, and involve the discovery of new means-ends relationships. In agreement with our findings, other authors' studies underline that individual perception of opportunities appears to be one of the main motivating factors triggering entrepreneurial behaviours $[11,13,14]$. Fear of failure, unlike the previous perceptual factor, measures a negative emotion resulting from the perception of different threats, and it is considered an inhibitor of venture creation [10]. In our analysis, for low income countries, both opportunity perception and fear of failure have similar values. Fear of failure is stronger in highly developed economies, i.e., the individuals who perceive a market opportunity for opening a business also express a higher fear of failure. This perceptual factor acts as a barrier in venture creation, and has a negative impact on TEA for both groups of countries. On the other hand, opportunity perception has stronger values for high developed economies, although this influence is not as high as anticipated. However, the perception of entrepreneurial opportunities could act as a precipitating factor, as it can reinforce other individual perceptions [52].

Of course, this study has several limitations. Some mainly relate to the data used from GEM Adult Population Survey, including mostly "yes" and "no" answers, which limits the use of a more accurate statistical analysis. Secondly, the number of items related to entrepreneurial perception and 
activities is small, and includes mostly one item measures. Future studies embracing larger datasets by including more countries could offer more robust data and enable us to create a more accurate image of the main determinants of entrepreneurial activities before, during, and after the recent economic crisis.

Also, our analysis uses Adult Population Survey for 18 European member states in 2007 and 2014. A longitudinal study could capture a clearer image of TEA main determinants. Moreover, we only used a few determinants of the entrepreneurial activities. Thus, a possible future direction of research would be to study additional economic and non-economic factors (cultural indicators; other demographic indicators - environment of provenance) which may influence TEA. The national culture dimensions, i.e., power distance, individualism/collectivism, masculinity/femininity, long/short term orientation, uncertainty avoidance and indulgence/restraint) [40] might provide a better understanding of the multifaceted relationship between economic development, country competitiveness and culture, and their impact on opportunity-driven and necessity-driven early-stage entrepreneurs. For future research, it may well be desirable to consider other European countries, as well as additional essential timelines to describe the evolution of these factors over time. In addition, it would be interesting to carry out a longitudinal study on the factors that could affect TEA. Likewise, applying qualitative methods to study more in depth this phenomen on might contribute to the improvement of the understanding of the factors and of their impact on opportunity-driven and necessity-driven early-stage entrepreneurs in different industries and different countries.

Author Contributions: The authors' contributions were equal. A.I.V. the introduction, designed the research, its reasoning, collected, analysed the data and discussed the data and performed the paper editing. G.I.B. and R.C.B. drafted the introduction, literature review, and edited the paper. All authors have read and agreed to the published version of the manuscript.

Funding: This research received no external funding.

Acknowledgments: The authors would like to thank the anonymous reviewers for their valuable comments and suggestions in improving the quality of the paper.

Conflicts of Interest: The authors declare no conflict of interest

\section{Appendix A}

Table A1. Sample distribution: involvement in TEA by country, 2007 and 2014.

\begin{tabular}{|c|c|c|c|c|c|c|c|c|c|c|}
\hline \multirow{3}{*}{ Country } & \multicolumn{10}{|c|}{ TEA } \\
\hline & \multicolumn{5}{|c|}{2007} & \multicolumn{5}{|c|}{2014} \\
\hline & No. & $\begin{array}{c}\text { Percentage } \\
(\%)\end{array}$ & Yes & $\begin{array}{l}\text { Percentage } \\
(\%)\end{array}$ & Total & No. & $\begin{array}{c}\text { Percentage } \\
(\%)\end{array}$ & Yes & $\begin{array}{c}\text { Percentage } \\
(\%)\end{array}$ & Total \\
\hline Belgium & 1968 & 97.0 & 60 & 3.0 & 2028 & 1894 & 94.5 & 110 & 5.5 & 2004 \\
\hline Croatia & 1864 & 93.2 & 136 & 6.8 & 2000 & 1833 & 91.6 & 167 & 8.4 & 2000 \\
\hline Denmark & 1891 & 94.5 & 110 & 5.5 & 2001 & 1897 & 94.5 & 111 & 5.5 & 2008 \\
\hline Finland & 1868 & 93.2 & 137 & 6.8 & 2005 & 1893 & 94.4 & 112 & 5.6 & 2005 \\
\hline France & 1959 & 97.7 & 46 & 2.3 & 2005 & 1921 & 95.8 & 84 & 4.2 & 2005 \\
\hline Germany & 3855 * & $95.2 *$ & 194 * & $4.8^{*}$ & $4049 *$ & 4052 & 94 & 259 & 6 & 4311 \\
\hline Greece & 1892 & 94.6 & 108 & 5.4 & 2000 & 1845 & 92.2 & 155 & 7.8 & 2000 \\
\hline Hungary & 1397 & 93.1 & 103 & 6.9 & 1500 & 1813 & 90.5 & 190 & 9.5 & 2003 \\
\hline Ireland & 1865 & 92.9 & 142 & 7.1 & 2007 & 1879 & 93.9 & 121 & 6.1 & 2000 \\
\hline Italy & 1920 & 96.0 & 80 & 4.0 & 2000 & 1910 & 95.5 & 90 & 4.5 & 2000 \\
\hline Latvia & 1919 & 95.9 & 81 & 4.1 & 2000 & $1746^{* *}$ & $87.2^{* *}$ & $258^{* *}$ & $12.8^{* *}$ & $2004^{* *}$ \\
\hline Netherlands & 3398 & 96.0 & 141 & 4.0 & 3539 & 2076 & 91.9 & 184 & 8.1 & 2260 \\
\hline Portugal & 1841 & 91.0 & 182 & 9.0 & 2023 & 1796 & 89.6 & 209 & 10.4 & 2005 \\
\hline Romania & 1994 & 97.5 & 52 & 2.5 & 2046 & 1781 & 89 & 220 & 11 & 2001 \\
\hline Slovenia & 2876 & 95.2 & 144 & 4.8 & 3020 & 1881 & 93.9 & 123 & 6.1 & 2004 \\
\hline Spain & 25843 & 92.7 & 2037 & 7.3 & 27,880 & 23736 & 94.9 & 1264 & 5.1 & 25,000 \\
\hline Sweden & 1932 & 96.6 & 69 & 3.4 & 2001 & 2346 & 93.5 & 162 & 6.5 & 2508 \\
\hline $\begin{array}{l}\text { United } \\
\text { Kingdom }\end{array}$ & 39876 & 95.3 & 1953 & 4.7 & 41,829 & 1849 & 92.1 & 158 & 7.9 & 2007 \\
\hline
\end{tabular}

Source: our own calculations. Note: * For Germany in 2007, we used the data from the previous year; ${ }^{* *}$ for Latvia in 2014, we used the data from the following year. 


\section{References}

1. Stel, A.; Carree, M.; Thurik, R. The Effect of Entrepreneurial Activity on National Economic Growth Small. Bus. Econ. 2005, 24, 311-321.

2. Dvouletý, O. Determinants of Nordic entrepreneurship. J. Small Bus. Enterp. Dev. 2017, 24, 12-33. [CrossRef]

3. Wong, P.K.; Ping Ho, Y.; Autio, E. Entrepreneurship, Innovation and Economic Growth: Evidence from GEM data. Small Bus. Econ. 2005, 24, 335-350. [CrossRef]

4. Brush, C.G.; de Bruin, A.; Welter, F. A gender-A ware frame work for women's entrepreneurship. Int. J. Gend. Entrep. 2009, 1, 8-24. [CrossRef]

5. Santos, S.C.; Caetano, A.; Spagnoli, P.; Fernandes Costa, S.; Neumeyer, X. Predictors of entrepreneurial activity before and during the European economic crisis. Int. Entrep. Manag. J. 2017, 13, 1263-1288. [CrossRef]

6. Özdemir, Ö.; Karadeniz, E. Investigating the factors affecting total entrepreneurial activities in Turkey. Metu Stud. Dev. 2011, 38, 275-290.

7. Peris-Ortiza, M.; Ferreirab, J.J.M.; Fernandesc, C.I. Do Total Early-stage Entrepreneurial Activities (TEAs) foster innovative practices in OECD countries? Technol. Forecast. Soc. Chang. Technol. Forecast. Soc. Chang. 2018, 129, 176-184. [CrossRef]

8. Beynon, M.J.; Jones, P.; Pickernell, D. Country-based comparison analysis using fsQCA investigating entrepreneurial attitudes and activity. J. Bus. Res. 2016, 69, 1271-1276. [CrossRef]

9. Haller, A.P.; Butnaru, R.C.; Butnaru, G.I. International Migrant Remittances in the Context of Economic and Social Sustainable Development. A comparative Study of Romania-Bulgaria. Sustainability 2018, 10, 1156. [CrossRef]

10. Albulescu, C.T.; Tamasila, M. The impact of FDI on entrepreneurship in the European Countries. Procedia Soc. Behav. Sci. 2014, 124, 219-228. [CrossRef]

11. Neill, S.; Metcalf, L.; York, J. Distinguishing entrepreneurial approaches to opportunity perception. Int. J. Entrep. Behav. Res. 2017, 23, 296-316. [CrossRef]

12. Shane, S.; Venkataraman, S. The Promise of Entrepreneurship as a Field of Research. Acad. Manag. Rev. 2000, 25, 217-226. [CrossRef]

13. Shane, S.; Locke, E.A.; Collins, C.J. Entrepreneurial motivation. Hum. Resour. Manag. Rev. 2003, 13, $257-279$. [CrossRef]

14. McMullen, J.S.; Shepherd, D.A. Entrepreneurial action and the role of uncertainty in the theory of the entrepreneur. Acad. Manag. Rev. 2006, 31, 132-152. [CrossRef]

15. Vodă, A.I.; Florea, N. Impact of Personality Traits and Entrepreneurship Education on Entrepreneurial Intentions of Business and Engineering Students. Sustainability 2019, 11, 1192. [CrossRef]

16. Velilla, J. Feminization of Entrepreneurship in Developing Countries? Evidence from GEM Data. 2017. Available online: https://mpra.ub.uni-muenchen.de/79997/MPRA (accessed on 3 July 2019).

17. Anton, S.G.; Bostan, I. The Role of Access to Finance in Explaining Cross-National Variation in Entrepreneurial Activity: A Panel Data Approach. Sustainability 2017, 9, 1947. [CrossRef]

18. Hessels, J.; van Gelderen, M.; Thurik, R. Entrepreneurial aspirations, motivations, and their drivers. Small Bus. Econ. 2008, 31, 323-339. [CrossRef]

19. Singer, S.; Amorós, J.E.; Arreola, D.M. 2015, Global Entrepreneurship Monitor 2014 Global Report. Available online: https://www.gemconsortium.org/report (accessed on 19 August 2019).

20. Micozzi, A.; Lucarelli, C. Heterogeneity in entrepreneurial intent: The role of gender across countries. Int.J. Gend. Entrep. 2016, 8, 173-194. [CrossRef]

21. Arafat, M.Y.; Saleem, I.; Dwivedi, A.K.; Khan, A. Determinants of agricultural entrepreneurship: A GEM data-based study. Int. Entrep. Manag. J. 2018, 1-26. [CrossRef]

22. Menard, S. Six Approaches to Calculating Standardized Logistic Regression Coefficients. Am. Stat. 2004, 58, 218-223. [CrossRef]

23. Bosma, N.; Kelley, D. Global Entrepreneurship Monitor 2018/2019 Global Report. 2019. Available online: https://www.gemconsortium.org/report (accessed on 22 August 2019).

24. Bönte, W. Entrepreneurship and Economic Growth. 2009. Available online: https://ec.europa.eu/economy_ finance/events/2009/20091120/boente_en.pdf (accessed on 19 August 2019).

25. Schmitz, J.A. Imitation, Entrepreneurship, and Long-Run Growth. J. Political Econ. 1989, 97, 721-739. [CrossRef] 
26. Kelley, D.; Singer, S.; Herrington, M. Global Entrepreneurship Monitor 2015/2016 Global Report. 2016. Available online: https://www.gemconsortium.org/report (accessed on 19 August 2019).

27. Bosma, N.; Jones, K.; Autio, E.; Levie, J. Global Entrepreneurship Monitor 2007 Global Report. 2008. Available online: https://www.gemconsortium.org/report (accessed on 19 August 2019).

28. Vogel, P. From Venture Idea to Venture Opportunity. Entrep. Theory Pract. 2017, 41, 943-971. [CrossRef]

29. Davidsson, P. Entrepreneurial opportunities and the entrepreneurship nexus: A re-conceptualization. J. Bus. Ventur. 2015, 30, 674-695. [CrossRef]

30. Foss, N.J.; Klein, P.G. Entrepreneurial discovery or creation? In search of the middle ground. Acad. Manag. Rev. 2017, 42, 4. [CrossRef]

31. European Commission. 2019, Female Entrepreneurs. Available online: https://ec.europa.eu/growth/smes/ promoting-entrepreneurship/we-work-for/women_en (accessed on 20 August 2019).

32. Haus, I.; Steinmetz, H.; Isidor, R.; Kabst, R. Gender effects on entrepreneurial intention: A meta-analytical structural equation model. Int. J. Gend. Entrep. 2013, 5, 130-156. [CrossRef]

33. Mueller, S.L.; Conway Dato-on, M. Across cultural study of gender-role orientation and entrepreneurial self-efficacy. Int. Entrep. Manag. J. 2013, 9, 1-20. [CrossRef]

34. Wilson, F.; Kickul, J.; Marlino, D.; Barbosa, S.D.; Griffiths, M.D. Ananalys is of the role of gender and self-efficacy in developing female entrepreneurial interest and behavior. J. Dev. Entrep. 2009, 14, 105-119.

35. Bohlmann, C.; Rauch, A.; Zacher, H. A Life span Perspective on Entrepreneurship: Perceived Opportunities and Skills Explain the Negative Association between Age and Entrepreneurial Activity. Front. Psychol. 2017, 8, 2015. [CrossRef]

36. Hatak, I.; Harms, R.; Fink, M. Age, job identification, and entrepreneurial intention. J. Manag. Psychol. 2014, 30, 38-53. [CrossRef]

37. Ardichvili, A.; Cardozo, R.; Ray, S. A theory of entrepreneurial opportunity identification and development. J. Bus. Ventur. 2003, 18, 105-123. [CrossRef]

38. Vaghely, I.P.; Julien, P.A. Are opportunities recognized or constructed? An information perspective on entrepreneurial opportunity identification. J. Bus. Ventur. 2010, 25, 73-86. [CrossRef]

39. Wennberg, K.; Pathak, S.; Autio, E. How culture moulds the effects of self-efficacy and fear of failure on entrepreneurship. Entrep. Reg. Dev. 2013, 25, 756-780. [CrossRef]

40. Hofstede, G. Management Scientists Are Human. Manag. Sci. 1994, 40, 4-13. [CrossRef]

41. Wyrwich, M.; Stuetzer, M.; Sternberg, R. Entrepreneurial role models, fear of failure, and institutional approval of entrepreneurship: A tale of two regions. Small Bus. Econ 2016, 46, 467-492. [CrossRef]

42. Amorós, J.E.; Bosma, N. Global Entrepreneurship Monitor 2013 Global Report. 2014. Available online: https://www.gemconsortium.org/report (accessed on 19 August 2019).

43. Wilson, F.; Kickul, J.; Marlino, D. Gender, Entrepreneurial Self-Efficacy, and Entrepreneurial Career Intentions: Implications for Entrepreneurship Education. Entrep. Theory Pract. 2007, 31, 387-406. [CrossRef]

44. Baum, J.R.; Locke, E.A. The Relationship of Entrepreneurial Traits, Skill, and Motivation to Subsequent Venture Growth. J. Appl. Psychol. 2004, 89, 587-598. [CrossRef]

45. Chaudhary, R. Demographic Factors, Personality and Entrepreneurial Inclination: A Study among Indian University Students. Educ. Train. 2017, 59, 171-187. [CrossRef]

46. Turkina, E. The importance of networking to entrepreneurship: Montreal's artificial intelligence cluster and its born-global firm Element AI. J. Small Bus. Entrep. 2018, 30, 1-8. [CrossRef]

47. Welter, F. Contextualizing Entrepreneurship-Conceptual Challenges and Ways Forward. Entrep. Theory Pract. 2011, 35, 165-184. [CrossRef]

48. Alayis, M.M.H.; Abdelwahed, N.A.A.; Atteya, N. Impact of Social Networking Sites Useon Entrepreneurial Intention among Undergraduate Business Students: The Case of Saudi Arabia. Int. J. Entrep. 2018, 22, 1-18.

49. Ratten, V.; Ferreira, J.; Fernandes, C. Entrepreneurial and network knowledge in emerging economies: A study of the Global Entrepreneurship Monitor. Rev. Int. Bus. Strategy 2016, 26, 392-409. [CrossRef]

50. Schmutzler, J.; Andonova, V.; Díaz Serrano, L. When Culture Does (not) Matter: Role Models and Self-Efficacy as Drivers of Entrepreneurial Behavior. Working Papers; 2072/247806. Universitat Rovirai Virgili, Department of Economics, 2015. Available online: https://www.recercat.cat/handle/2072/247806 (accessed on 28 January 2020).

51. The World Bank. Gross Domestic Product (Current US\$). Data All Countries And Economies. 2019. Available online: https://data.worldbank.org/indicator/NY.GDP.MKTP.CD (accessed on 21 August 2019). 
52. Liñán, F.; Santos, F.J.; Fernández, J. The influence of perceptions on potential entrepreneurs. Int. Entrep. Manag. J. 2011, 7, 373-390. [CrossRef]

53. Acs, Z.J.; Audretsch, D.B.; Braunerhjelm, P.; Carlsson, B. Growth and Entrepreneurship: An Empirial Assessment. Papers on Entrepreneurship, Growth and Public Policy. 2005. 3205. Available online: https://www.econstor.eu/handle/10419/24892 (accessed on 28 January 2020).

54. Stuetzer, M.; Audretsch, D.B.; Obschonka, M.; Gosling, S.D.; Rentfrow, P.J.; Potter, J. Entrepreneurship culture, knowledge spillovers and the growth of regions. Reg. Stud. 2018, 52, 608-618. [CrossRef]

55. Carter, S.; Anderson, S.; Shaw, E. Women's Business Ownership: A Review of the Academic, Popular and Internet Literature. Report to the Small Business Service; 2006. Available online: https://webarchive. nationalarchives.gov.uk/20090609014920/http://www.berr.gov.uk/files/file38362.pdf (accessed on 28 January 2020).

56. Sánchez-Escobedo, M.C.; Fernández-Portillo, A.; Díaz-Casero, J.C.; Hernández-Mogollón, R. Research in entrepreneurship using GEM data. Approach to the state of affairs in gender studies. Eur. J. Manag. Bus. Econ. 2016, 25, 150-160. [CrossRef]

57. Brush, C.; Ali, A.; Kelley, D.; Greene, P. The influence of human capital factors and context on women's entrepreneurship: Which matters more? J. Bus. Ventur. Insights 2017, 8, 105-113. [CrossRef]

58. Colovic, A.; Lamotte, O.; Bayon, M.C. Technology Adoption and Product Innovation by Third-Age Entrepreneurs: Evidence from GEM Data. In Handbook of Research on Elderly Entrepreneurship; Springer: Berlin/Heidelberg, Germany, 2019; pp. 111-124.

59. Velilla, J. The Entrepreneurial Activity Using GEM Data: Evidence for Spain (National and Regional) and for Europe. 2018. MPRA Paper No. 85568. Available online: https://mpra.ub.uni-muenchen.de/85568/ (accessed on 21 August 2019).

60. Menard, S. Standards for standardized logistic regression coefficients. Soc. Forces 2011, 89, 1409-1428. [CrossRef]

61. Thurik, A.R.; Uhlaner, L.; Wennekers, S. Entrepreneurship and its conditions: A macro perspective. Int. J. Entrep. Educ. 2002, 1, 25-64.

62. Carlsson, B. Small business, flexible technology, and industrial dynamics. In Small Business in the Modern Economy; Admiral, P.H., Ed.; Blackwell: Oxford, UK, 1996; pp. 63-125.

63. Clercq, D.D.; Arenius, P. The role of knowledge in business start-up activity. Int. Small Bus. J. 2006, 24, 339-358. [CrossRef]

64. Justo, R.; DeCastro, J.O.; Maydeu-Olivares, A. Indicators of entrepreneurship activity: Some methodological contributions. Int. J. Entrep. Small Bus. 2008, 6, 604-621. [CrossRef] 